\title{
Antarctic microbial communities are functionally redundant, adapted and resistant to short term temperature perturbations
}

de Scally, S.Z. ${ }^{1}$, Makhalanyane, T.P. ${ }^{1 \#}$, Frossard, A. ${ }^{1}$, Hogg, I.D. ${ }^{2}$, and Cowan, D.A. ${ }^{1}$

${ }^{1}$ Centre for Microbial Ecology and Genomics (CMEG), Department of Genetics, Natural Sciences 2, University of Pretoria, Hatfield, Pretoria, 0028

${ }^{2}$ School of Science, University of Waikato, Hamilton 3240, New Zealand

Running title: Antarctic soil microbial responses to warming

Original research article

\#Corresponding author: Dr. T.P. Makhalanyane

Department of Genetics

Centre for Microbial Ecology and Genomics

Natural Sciences 2

University of Pretoria

Private Bag X20, Hatfield

Pretoria

0028

Email: thulani.makhalanyane@up.ac.za

Tel: 0027124206976

Keywords: Antarctica, climate change, ecosystem processes, microcosm, microbial diversity 


\begin{abstract}
Climate change has the potential to induce dramatic shifts in the biodiversity and functionality of soil microorganisms in polar hyperarid ecosystems. In these depauperate soil ecosystems, microbial communities are vital as they represent the dominant input sources of essential nutrients. However, the effects of changing climate on extreme edaphic environments, such as the McMurdo Dry Valleys of Antarctica, remain poorly understood. To better understand these effects, we constructed soil microcosms and simulated temperature shifts over a 40-day period. Soil physicochemical analysis revealed low levels of key nutrients, with mean organic carbon and nitrogen contents of $<0.1 \%$ and $11.55 \mathrm{ppm}$, respectively. We also applied 16S rRNA gene amplicon sequencing to determine taxonomic composition and enzyme assays to measure in situ activity. Our data showed a prevalence of ubiquitous soil taxa (Actinobacteria, Chloroflexi and Deinococcus-Thermus), with a smaller proportion of autotrophic phyla (i.e. Cyanobacteria). None of the major phyla showed relative abundance changes in response to temperature. We found very low extracellular enzyme activity levels across all samples and observed no significant differences among temperature treatments. Functional predictions (using PICRUSt) revealed the putative presence of key genes implicated in the cycling of carbon $(p p c, r b c l)$ and nitrogen $(n i f H$, nirK), in stress response and in DNA repair throughout all treatments. Overall, our results suggest that short-term temperature fluctuations do not alter microbial biodiversity and functionality in Antarctic soils. This study provides the first evidence that microbial communities within this edaphic extreme environment may be functionally redundant, adapted and resistant to short term climatic perturbations.
\end{abstract}




\section{Introduction}

Global temperatures are expected to rise by up to $6.4^{\circ} \mathrm{C}$ within the next 100 years, largely due to the effects of anthropogenic climate change (IPCC, 2007; Singh et al., 2010; Clements et al., 2014). Rising temperatures lead to the melting of surface and shallow sub-surface ice, resulting in the mobilisation of water and nutrients in polar terrestrial habitats, which are large carbon reservoirs (Singh et al., 2010; Isbell et al., 2015). Microbial communities are the dominant biota within these terrestrial habitats and are also known mediators of key biogeochemical cycles, particularly carbon and nitrogen turnover (Singh et al., 2010; Cowan et al., 2014). It is therefore hypothesised that changes in soil microbial community diversity and function may lead to alterations in essential ecosystem cycles (Singh et al., 2010; Gutknecht et al., 2012). However, it remains unclear how soil microbial communities may respond to temperature increases (Cowan et al., 2014), especially within climatically sensitive regions such as the McMurdo Dry Valleys (MDVs) of Antarctica (Cowan and Ah Tow, 2004; Barrett et al., 2006; Pointing et al., 2009).

The MDV mineral soils represent an ideal ecosystem in which to assess the effects of climatic changes due to their trophic simplicity and microbially driven nature (Cowan and Ah Tow, 2004; Pointing et al., 2009). However, field studies are limited within the MDVs due to the challenging environmental conditions and strict regulations designed to protect the Antarctic region (Cowan and Ah Tow, 2004). Microcosms, which are laboratory based studies, allow the creation of artificial environments within which the effects of perturbations may be assessed under controlled conditions (Grenni et al., 2012; Martínez et al., 2014). Although microcosms cannot account for the complete complexity of the natural environment (Grenni et al., 2012), such studies have shown reliable results (Grenni et al., 2012; Blake et al., 2015) which are comparable to studies performed in the field (Treonis et al., 2002; Martínez et al., 2014).

The microbial diversity of MDV soils is surprisingly high (Aislabie et al., 2006; Niederberger et al., 2008; Dreesens et al., 2014; Richter et al., 2014). The microbial communities in these edaphic regions have also been shown to harbour the capacity for complex metabolic functions (Yergeau et al., 2007a; Hopkins et al., 2008; Chan et al., 2013), with multiple genes for key pathways in carbon and nitrogen cycling (Yergeau et al., 2007a; Chan et al., 2013). Soil respiration (Hopkins et al., 
2006), extracellular enzyme activities (Hopkins et al., 2008) and acetylene reduction (a valid proxy for nitrogen fixation) (Niederberger et al., 2008) have all been detected in MDV soils. These studies indicate that microbial communities within the MDV region have the capacity to contribute to functional ecosystem processes (Barrett et al., 2006; Cowan et al., 2014).

Microbial communities within Antarctic soils may respond relatively rapidly to environmental changes (Stomeo et al., 2012; Tiao et al., 2012). For instance, the repositioning of a mummified seal carcass led to rapid (within three years) changes in the underlying soil microbial community structure (Tiao et al., 2012). In addition, a number of studies assessing microbial diversity and abiotic factors along Antarctic latitudinal gradients have shown that community structure and functionality may be potentially altered in response to temperature (Rinnan et al., 2009; Newsham et al., 2015), moisture (Stomeo et al., 2012) and soil physiochemical status (Lee et al., 2012; Stomeo et al., 2012). However, how MDV soil microbial communities may respond directly to climatic perturbations, as well as how rapidly, is still unclear (García-Palacios et al., 2015).

Two hypotheses concerning the predicted response of microbial communities to climatic change have been proposed. The community diversity hypothesis (Isbell et al., 2015) suggests functional redundancy among organisms and that losses in diversity will not lead to decreases in function. Alternatively, the keystone species hypothesis (Pold and Deangelis, 2013) proposes that loss of a few key taxa will lead to lower functionality and thus there is little functional redundancy. In support of this hypothesis, studies have found that microbial abundance and diversity may increase in response to temperature changes, while maintaining functional capacity (Yergeau and Kowalchuk, 2008; Newsham et al., 2015). Similarly, a decline in microbial biomass in response to temperature can be associated with an increase in soil respiration (Laudicina et al., 2015). However, other studies have shown that higher temperatures lead to a decrease in microbial species richness (Jung et al., 2011; Dennis et al., 2013; Philippot et al., 2013). This may, in turn, lead to a reduction in functional gene abundance (Jung et al., 2011) and microbial activity (Hopkins et al., 2006; Philippot et al., 2013). Such conflicting results indicate that the exact effects of climatic changes on microbial diversity and functionality, and subsequent ecosystem processes, remain unresolved (García-Palacios et al., 2015). 
Here, we examine the influence of short term temperature fluctuations on Antarctic soil microbial community diversity and potential functionality. Microcosms were constructed using soil samples collected from the MDVs. Three temperature treatments were then applied to the microcosms for a period of forty days, where a baseline sample was taken prior to the start of the experiment and samples were recovered periodically. We used 16S rRNA gene amplicon sequencing to assess microbial diversity changes. The activity of extracellular enzymes potentially involved in microbial nutrient acquisition were combined with PICRUSt and KEGG functional gene and pathway predictions to assess potential microbial functionality.

\section{Materials and Methods}

\subsection{Soil sample collection and physicochemical analysis}

Approximately $4 \mathrm{~kg}$ of mineral soil was collected in the vicinity of Spalding Pond in the Taylor Valley region of the McMurdo Dry Valleys, Antarctica $\left(77.65808^{\circ} \mathrm{S}, 163.09204^{\circ} \mathrm{E}\right)$ in January 2015 (Figure 1). Soil was collected aseptically by retrieving the top $5 \mathrm{~cm}$ of soil within a $20 \times 20 \mathrm{~cm}$ sampling area. Soil was placed in sterile plastic bags and stored at $-30^{\circ} \mathrm{C}$. All necessary permits were obtained through Antarctica New Zealand and the New Zealand Ministry of Foreign Affairs and Trade (MFAT) to allow the removal of the soil. The soil was then shipped on dry ice to the Centre for Microbial Ecology and Genomics (CMEG) at the University of Pretoria, where it was stored at $-80^{\circ} \mathrm{C}$. Soil physiochemical analyses were performed at the Department of Plant Production and Soil Science of the University of Pretoria on three replicate soil samples prior to the microcosm experiment. Soil particle size was determined using the hydrometer method, as previously described (Bouyoucos, 1962). Percentage organic carbon analysis was performed according to the Walkley and Black method (Walkley and Black, 1934). Soil pH was determined using a glass electrode with a water-to-soil ratio of $2.5: 1$, according to specifications previously provided (Coleman, 1967). Ion concentrations were determined using potassium chloride (Bremner and Keeney, 1966), ammonium acetate (Chapman, 1965) and P- Bray I (Bray and Kurtz, 1945) extractions. The cation exchange capacity of the soil was determined according to a previously described method (Gillman et al., 1983). 


\subsection{Microcosm set-up}

To determine the effect of increasing and fluctuating temperatures on Antarctic soil microbial communities, a microcosm experiment was designed. Soil samples were randomly assigned to three temperature treatment groups. Temperature simulations were applied over a period of forty days, wherein samples were taken 10 days prior to the start of the experiment and in 5 day intervals thereafter (Figure S1, S2). The treatment groups consisted of a control temperature group, at $0^{\circ} \mathrm{C}$ for the entire experiment and two temperature treatment groups. One treatment group, called "stable" was at a constant elevated temperature of $15^{\circ} \mathrm{C}$. The other treatment group, called "fluctuating" varied from 0 to $15^{\circ} \mathrm{C}$ with $1.5^{\circ} \mathrm{C}$ increments per day, remained at $15^{\circ} \mathrm{C}$ for 10 days and was then decreased from 15 to $0^{\circ} \mathrm{C}$ with $1.5^{\circ} \mathrm{C}$ increments per day (Figure S1). The start of the experiment is indicated as day 0 , where the control and fluctuating treatment groups were at $0^{\circ} \mathrm{C}$, whereas the stable treatment group was at $15^{\circ} \mathrm{C}$. Ten days prior to the start of the microcosm experiment, the stable treatment group was increased from 0 to $15^{\circ} \mathrm{C}$ with $1.5^{\circ} \mathrm{C}$ increments per day (Figure S1, day -10). Further details of the experimental procedure are present in Supplementary Methods and Materials and are available on the online version of this manuscript.

\subsection{Microcosm experiment analysis}

\subsubsection{Microbial community analysis using Illumina-based amplicon sequencing}

DNA extractions were performed using a MoBio PowerSoil $®$ DNA Isolation Kit (MoBio, Carlsbad, USA) according to the manufacturer's instructions. The replicates of each treatment group taken at each sampling point were pooled prior to sequencing to obtain an equimolar concentration of each replicate in the final reaction. DNA samples were then sent to MRDNA (www.mrdnalab.com, Shallowater, USA) for sequencing. The primers used for PCR amplification were 515F (5'GTGCCAGCMGCCGCGGTAA-3') and 806R (5'-GGACTACVSGGGTATCTAAT-3') (Caporaso et al., 2011), which specifically target both the bacterial and archaeal V4 hypervariable region of the 16S rRNA gene. The samples had a barcode added to the forward primer to allow for multiplex sequencing and paired-end sequencing was performed on an Illumina MiSeq platform according to the manufacturer's instructions. 
Sequencing analyses were performed using the Quantitative Insights into Microbial Ecology (QIIME) software package (Caporaso et al., 2010). Sequences were demultiplexed, quality filtered and split into samples according to barcode sequences. Quality filtering involved removing sequences with less than 400 nucleotides, greater than 1000 nucleotides, an average quality score of less than 25, homopolymer runs larger than 6 bases, greater than 6 ambiguous bases, all primer mismatches and any barcode errors greater than 1.5. Chimeras were identified and removed using the USEARCH method and the Greengenes reference library (Desantis et al., 2006). Operational taxonomic unit (OTU) definition and taxonomic assignment was performed to the default of $97 \%$ sequence identity using the Greengenes reference library. Singletons were removed by specifying two as the minimum number of times an OTU must appear to be retained. The dataset was rarefied to 22,400 sequences per sample.

\subsubsection{Microbial community potential functionality analysis}

\section{PICRUSt functional predictions}

Functional pathway and marker gene prediction was performed using an OTU table generated from QIIME, PICRUSt software and KEGG orthology (Langille et al., 2013). Following the online protocol, the OTU table was normalized by copy number to ensure that the abundances of each OTU were normalised to the number of $16 \mathrm{~S}$ rRNA genes occurring within a specific OTU. The normalised OTU table was then used to convert the 16S rRNA gene sequencing data into a predicted metagenome for each sample using the reference database. PICRUSt can only assign function to OTUs occurring within the reference (Greengenes) database and therefore New.ReferenceOTUs. and New.CleanUp.ReferenceOTUs were removed, decreasing the number of OTUs identified in the original dataset from 8,843 to 769 . After a predicted metagenome was created from PICRUSt, cellular pathway and marker gene assignment to each sample was performed using KEGG orthology (Kanehisa and Goto, 2000; Kanehisa et al., 2014).

\section{Extracellular enzyme assays}

Potential activities of seven extracellular enzymes involved in carbon [ $\beta$-glucosidase (BX), $\beta$ xylosidase $(\mathrm{BG})$ and phenol oxidase/peroxidase (PO/PPO)], nitrogen [N-acetyl glucosaminidase 
(NAG), leucine aminopeptidase (LAP)] and phosphorus [alkaline phosphatase (AP)] acquisition were assessed. Substrate analogues linked to 4-methylumbelliferone (MUB) or 7-aminocoumine (AMC) for the fluorescent assays and L-3,4- dihydroxyphylalanine (L-DOPA) for the colorimetric assays were used. The experimental procedure was performed as previously described (Sinsabaugh et al., 2008). Briefly, $5 \mathrm{~g}$ of samples were mixed with $100 \mathrm{~mL}$ of $0.1 \mathrm{M}$ Tris buffer (pH 9.9) and the resulting sample slurry was stirred to ensure homogenisation. Aliquots of $200 \mu \mathrm{L}$ were added to 96-well microplates, with four replicated wells per sample per enzyme assay. Plates were then incubated for 3 hours at $7^{\circ} \mathrm{C}$ in the dark. Fluorescence and absorbance measurements were then taken on a Spectramax® Paradigm Multi-Mode Microplate Reader (Molecular Devices, USA) and a ThermoScientific Multiskan GO spectrophotometer (ThermoScientific, USA), respectively. Enzyme activities were calculated according to equations previously described (Sinsabaugh, 1994; German et al., 2011).

\subsection{Statistical analysis}

All statistical analyses were performed using either the $\mathrm{R}$ statistical package version 3.2.2 ( $\mathrm{R}$ Core Team, 2013), or PAST version 2.17 (Hammer et al., 2004). Microbial diversity was analysed using the $\mathrm{R}$ statistical package. Alpha-, beta- and gamma- diversity were calculated using the vegan package in R. Significant differences in diversity metrics between treatment groups and sampling days were determined using a one-way ANOVA analysis via the aov function of the vegan package in $\mathrm{R}$, as well as post-hoc TukeyHSD tests. Venn diagrams were generated with both the vegan package in $\mathrm{R}$ to create a biological distance matrix using Bray-Curtis similarity and the gplots package to create the final diagram. Permutational multivariate analysis of variance (PERMANOVA) was used to detect significant differences in microbial community composition between treatment groups and sampling days. PERMANOVA was performed using the adonis function in R with 999 random permutations to determine statistical significance. Analysis of similarity (ANOSIM) was performed on taxonomic data to analyse the similarity between treatment groups using the anosim function of the vegan package in $\mathrm{R}$ with 999 random permutations.

A two-dimensional non-metric multidimensional scaling (NMDS) ordination of sequencing data was generated using Bray-Curtis similarity and the meta.nmds function of the vegan package in R. A 
redundancy analysis (RDA) was performed on sequencing data using the rda function of the vegan package in R. Enzyme assays were added to the RDA ordination plot as vectors using the envfit function of the vegan package in $\mathrm{R}$, and significant drivers were determined via permutational analysis at a cut-off $p$-value of 0.05 . Statistically significant differences $(p<0.5)$ between days and treatment groups for each enzyme assay were determined using one-way ANOVA in PAST. To determine where significant differences occurred, post-hoc TukeyHSD analyses were performed. Statistically significant differences between treatment groups for pathway data were determined using PERMANOVA via the adonis function in R. A heatmap of pathway data was created using the ggplot2, reshape2, plyr and scales packages in $\mathrm{R}$.

\subsection{Accession numbers}

The sequence data generated from this study have been deposited in the Short Read Archive (SRA) of the National Centre for Biotechnology Information (accession number SRP067320).

\section{Results and discussion}

\subsection{Physiochemical analysis of soil}

Soil physiochemical data is summarised in Table 1. The percentage of sand was very high (97\%) whereas the silt and clay proportion were comparatively low ( $3 \%$ combined). The abundance of organic matter was also low, with a mean organic carbon content of $0.093 \%(w / w)$. The average $\mathrm{pH}$ value of the soil was 9.9 and the cation exchange capacity (CEC) of the soil was $8.29 \mathrm{cmol} / \mathrm{kg}$, which reflects the dominance of the sand fraction in these soils. Sodium ( $\mathrm{Na}$ ) and calcium (Ca) were found to have the highest concentrations (127.41 and $110.94 \mathrm{ppm}$, respectively) whereas magnesium $(\mathrm{Mg})$ and phosphorus $(\mathrm{P})$ were found to have the lowest concentrations (17.42 and $7.69 \mathrm{ppm}$, respectively). The inorganic nitrogen composition of the soil, indicated by the ammonium $\left(\mathrm{NH}_{4}\right)$ and nitrate $\left(\mathrm{NO}_{3}\right)$ concentrations, was found to be $11.55 \mathrm{ppm}$. These findings are consistent to previous soil analysis from Dry Valley soils and confirm that these soils are highly oligotrophic (Lee et al., 2012; Makhalanyane et al., 2013). The physiochemical characteristics and resulting oligotrophic nature of MDV soils strongly influences the microbial diversity present (Stomeo et al., 2012). 


\subsection{Microbial community diversity analysis}

The total number of OTUs identified from the sequencing analysis at a taxonomic assignment similarity cut-off of $97 \%$, following singleton removal, was 8,834 . The percentage of OTUs unique to each temperature group across the experimental time period was as follows; the control temperature treatment group harboured the highest number of unique OTUs $(30 \%)$, whereas the fluctuating and stable treatment groups had slightly lower percentages of unique OTUs, with $24 \%$ and $21 \%$, respectively. The percentage of OTUs shared among all three treatment groups (13\%) was less than the percentage of OTUs unique to each group. Despite the differences observed among treatment groups in terms of OTU abundance, none were statistically significantly different based on PERMANONVA analysis (999 random permutations). An ANOSIM analysis of OTU similarity among groups indicated that the groups were almost identical $(R=0.0065, p>0.5)$. A twodimensional (2D) non-metric multidimensional scaling (NMDS) ordination of OTU data (Figure S3) shows no clustering of samples according to treatment group.

Alpha-diversity was determined as both the number of observed OTUs and the Shannon diversity index $\left(H^{\prime}\right.$ index) for each sample (Table 2). A high $H^{\prime}$ index was found for all three of the temperature treatment groups. This result, along with the high number of observed OTUs, indicates a high species richness within each treatment group (Niederberger et al., 2008). These findings are similar to previous studies on Antarctic soil microbial diversity, where $\mathrm{H}^{\prime}$ index values and the number of observed OTUs range between approximately 1.5 to 7 (Niederberger et al., 2008; Teixeira et al., 2010; Pessi et al., 2012; Wang et al., 2015) and between approximately 10 to > 4500 (Teixeira et al., 2010; Lee et al., 2012; Wang et al., 2015), respectively. No statistically significant differences in alpha diversity were found between temperature treatments using oneway ANOVA.

Beta-diversity was calculated using the Whittaker or y/a diversity measure (Table 2) and one-way ANOVA showed no statistically significant differences in beta-diversity between temperature treatment groups. Gamma diversity for the three treatment groups (Table 2) and each sampling day (Table S1) remained relatively high, and was substantially higher than previously detected in Antarctic soils. For example, a study surveying soil microbial diversity across several MDV regions 
found gamma diversity values in the range of 136-218 (Sokol et al., 2013), several orders of magnitude lower than detected in this study.

No statistically significant differences in diversity measures were observed in response to the temperature simulations. This finding is contrary to expectations that soil warming is likely to lead to relative changes in compositional microbial diversity (Zogg et al., 1997; Pessi et al., 2012; Okie et al., 2015). However, previous studies have also shown that microbial diversity may remain relatively unaffected by increased temperatures. For example, a study which assessed the effects of experimental warming on microbial communities in temperate mountain forest soils found that warming did not affect the abundance of most microbial groups (Schindlbacher et al., 2011). In the present study, the maintenance of high diversity values across all three temperature treatments is in line with the community diversity hypothesis (Pold and Deangelis, 2013). These results suggest that the microbial communities present may be resistant to the short-term imposed temperature perturbations, resulting in the non-responsive nature of these communities.

Little variation in microbial taxonomy was observed among treatment groups and sampling days. Figures 3 and 4 show the relative abundance of OTUs classified to phylum level and are plotted according to either treatment (Figure 3) or sampling day (Figure 4). These figures show that the majority of phyla identified are at a relatively low abundance, with only three phyla occurring at a frequency of more than $15 \%$. The most abundant phyla in all samples were affiliated with bacteria, including Actinobacteria, Chloroflexi and Deinococcus-Thermus. These phyla are ubiquitously distributed in cold environments and particularly in Antarctic soils (Yergeau et al., 2007b; Fierer et al., 2012; Cowan et al., 2014). The abundance of the three dominant phyla at Class level did not differ among the three treatments, or sampling days (Figures S4-S6). Interestingly, Proteobacteria and Gemmatimonadetes occurred with a mean abundance of only $\pm 6 \%$ each throughout the three treatments, in contrast to previous studies where they were found to dominate Antarctic soils (Makhalanyane et al., 2013). However, Proteobacteria are known to prefer more nutrient rich habitats (Yergeau et al., 2012), which may explain their lower abundance in the nutrient poor soils analysed in this study. 
Cyanobacteria $(0.2 \%)$ were found in almost all samples at all sampling points, although their abundance did not differ across days or treatments. Other identified phyla (Figures 3 and 4) occurred at an abundance of less than $4 \%$ across all treatments and sampling days. The percentage of unassigned sequences was low, with a mean of $0.57 \%$, indicating good taxonomic assignment of the sequencing data.

The dominant bacterial phyla identified in this study are all known to harbour members highly resistant to extreme environmental conditions (Margulis and Chapman, 2009; Oren and Papke, 2010). The majority of phyla identified also contained members with heterotrophic physiologies (Oren and Papke, 2010; Shivlata and Tulasi, 2015; Thiel et al., 2015), capable of degrading complex organic compounds (Oren and Papke, 2010). Autotrophic taxa were also identified within all treatment groups, which is consistent to previous findings in Antarctic soils (Makhalanyane et al., 2015).

Archaea were found to be present at a very low abundance, with only two phyla identified, Crenarchaeota and Euryarchaeota. Euryarchaeota was present in only one sample, at an abundance of $0.007 \%$. Crenarchaeota were found to occur consistently in all samples at a mean abundance of $0.42 \%$. The low abundance of these taxa in Antarctic soils is consistent with previous findings from cold desert soils (Pointing et al., 2009).

Overall, no significant shift in the relative abundance of bacterial and archaeal taxa was observed, in contrast to observations from more benign Antarctic soils (Yergeau and Kowalchuk, 2008). However, in comparison, Dry Valley soils are severely oligotrophic and water limited (Cowan et al., 2014). It has previously been proposed that nutrient and water limitation may limit the ability of Antarctic soils to respond to changes due to warming (Wynn-Williams, 1996; Treonis et al., 2002). Our results suggest that this limitation also extends to microbial communities in these habitats.

\subsection{Microbial community potential functionality analysis}

PICRUSt and KEGG orthology assigned putative metabolic pathways and their associated marker genes involved in an array of cellular functions to each sample by creating predicted metagenomes. While these predictions are only indicative of putative functional capacity, previous 
studies have shown that PICRUSt analysis yields reliable results (Xu et al., 2014; Hill et al., 2015). Figure 5 shows a heatmap of predictive cellular pathways identified within all samples, with those considered most relevant to this study highlighted with a red box (environmental adaptation, DNA repair, and metabolism). No statistically significant differences were found between temperature treatment groups for any of the predictive pathways identified (PERMANOVA, P > 0.05) (Figure 5). Similarly, the graphical differences observed in Figure 5 between sampling dates within each treatment group were found to be non-significant (PERMANOVA, $P>0.05$ ). Rather, a consistent putative activity for all identified pathways can be seen throughout all temperature treatment groups. Key pathways (highlighted with a red box in Figure 5) along with their associated functions and marker genes, are indicated in Table 3. Figure 5, in conjunction with Table 3, shows that cellular processes involved in stress adaptation to both cold and heat stress were potentially present in all samples. Carbon fixation potential was also predicted for all samples, as was the potential for nitrogen metabolism, including nitrogen fixation, denitrification and ammonification.

Cellular pathways and marker genes identified using PICRUSt software (Langille et al., 2013) and KEGG orthology (Kanehisa et al., 2014) correlated with the characteristics of the observed taxa. For example, the prediction of pathways involved in carbohydrate, energy and amino acid metabolism (Table 3) was consistent with the predicted heterotrophic physiologies of the majority of identified taxa, such as Deinococcus-Thermus, Proteobacteria, Actinobacteria, Chloroflexi and Gemmatimonadetes (Margulis and Chapman, 2009; Oren and Papke, 2010; Shivlata and Tulasi, 2015; Thiel et al., 2015). As heterotrophic microorganisms are known to degrade complex substrates (Kuffner et al., 2012), these correlations suggest the involvement of the identified taxa in these pathways. Putative pathways and marker genes involved in carbon and nitrogen cycling were consistent with the continuous presence of both autotrophic and heterotrophic taxa. Some identified members of Actinobacteria, such as the genus Streptomyces and family Frankiaceae are capable of nitrogen fixation (Shivlata and Tulasi, 2015). Two identified orders of the phylum Chloroflexi, Chloroflexales and Herpetosiphonales, as well as the class Alphaproteobacteria of the phylum Proteobacteria, contain members capable of carbon assimilation (Campbell et al., 2014; Imam et al., 2015). The photoautotrophic phylum Cyanobacteria, which was also consistently 
present throughout the three treatment groups at a low mean abundance (Figures 3,4), is capable of carbon acquisition and therefore potentially plays a role in energy metabolism (Pointing et al., 2009; Durall and Lindblad, 2015).

The putative presence of genes involved in environmental adaptation and stress response is correlated to the predicted stress-tolerant physiologies of the observed taxa. For example, members of the phyla Deinococcus-Thermus and Actinobacteria are known to be highly desiccation and stress tolerant (Oren and Papke, 2010; Shivlata and Tulasi, 2015; Thiel et al., 2015), suggesting a correlation between the presence of these taxa and the putative identification of environmental adaptation as well as replication and repair pathways (Table 3 ). While these predictions are only indicative of the potential presence of the identified genes and cellular pathways, their abundance is consistent with previous functional diversity surveys within Antarctic soils (Pearce et al., 2012; Chan et al., 2013). The consistent presence of stress-tolerant taxa and marker genes throughout induced temperature fluctuations in this study may indicate resistance of the soil microbial communities to short-term temperature perturbations.

Activities were detected for four of the seven extracellular enzymes analysed, with little variability in activity between the three temperature treatments (control, fluctuating and stable). Phenol oxidase (PO) showed the highest overall activity (up to $60 \mathrm{nmol} \mathrm{h}{ }^{-1} \mathrm{~g}^{-1}$, Figure $6 \mathrm{~A}$ ), followed by phenol peroxidase (PPO), where a slightly lower activity was detected (53 $\mathrm{nmol} \mathrm{h}{ }^{-1} \mathrm{~g}^{-1}$; Figure $\left.6 \mathrm{~B}\right)$. No statistically significant differences were found for the PO and PPO assays between the three temperature treatment groups $\left(F_{2,6}, p>0.05\right)$. When compared to the redundancy analysis ordination of the bacterial community structure, the PO activity showed a significant linkage to the bacterial clustering $\left(R^{2}=0.7784, p<0.01\right)$, although the direction of the PO arrow did not point to any specific temperature treatment group (Figure 7). This may potentially indicate that the microbial communities present were consistently producing these extracellular enzymes, with no change in production in response to temperature fluctuations.

No significant difference was found between the temperature treatments for the AP assay $\left(F_{2,6}, p>\right.$ 0.05). The average observed AP activity was consistently low throughout temperature treatments, where the highest observed activity was $4 \mathrm{nmol} \mathrm{h}^{-1} \mathrm{~g}^{-1}$ (Figure 6C). LAP activity was consistently 
observed for all samples at all sampling days (except day 10), although at lower rates (Figure 6D) and no statistically significant differences between temperature treatment groups were observed. However, permutational analysis indicated that LAP was significantly linked to the ordinated bacterial community structure $\left(R^{2}=0.4891, P<0.01\right)$ and the direction of the arrow of the LAP activity pointed mainly towards fluctuating treatments samples (Figure 7). No activities were detected for the enzymes $\beta$-xylosidase $(B G), \beta$-glucosidase $(B X)$ or $N$-acetyl glucosaminidase (NAG) (Table 4).

Although metabolic potential for $\mathrm{C}, \mathrm{N}$ and $\mathrm{P}$ transformation have been previously observed in MDV soils, the low extracellular enzyme activities observed in this study may be due to the highly oligotrophic nature of the soil, in which the extremely low organic carbon and nitrogen supply may have limited enzyme biosynthesis (Hopkins et al., 2008). Increased temperature (either the stable or fluctuating increase) had no direct effect on any enzyme activity tested, which is in contrast to an empirical model prediction based on in situ measurement of potential microbial activities in Arctic soils (Wallenstein et al., 2009). However, the lack of an observable temperature effect was consistent with previous field studies conducted in the MDVs (Hopkins et al., 2008) and the Arctic (Melle et al., 2015; Seo et al., 2015). The lack of an observable temperature effect on microbial activities may also be a consequence of the very low soil organic carbon availability, as in alpine ecosystems, limited labile carbon availability can reduce the temperature sensitivity of organic matter mineralization (Song et al., 2010).

The significant link of LAP activity, an enzyme involved in the acquisition of nitrogen, and the bacterial community structure (Figure 7), may indicate particular nitrogen limited conditions. Moreover, LAP was especially linked with the fluctuating temperature treatments indicating that enzyme activities might be enhanced when soil conditions are changing. This is similar to a previous study done in alpine, arctic and sub-arctic soils, where the highest enzyme activities were found to rise in spring, during conditions of increasing temperatures and thaw (Jefferies et al., 2010). Therefore, the effect of temperature changes on microbial activities may occur during changing soil conditions, although such changes may need longer time periods (i.e. longer than 40 days) to be observed. 
The lack of observable changes in microbial diversity measures, taxonomic identities, extracellular enzyme activities as well as putative pathways and marker genes, suggests that MDV microbial communities may be adapted and resistant to short term changes. However, it is possible that the apparent stability detected in this study could be masking several other changes. For example, an initial increase in microbial activity in response to increased temperature, may be followed by a subsequent decrease due to the depletion of labile substrates, such as organic carbon (Bradford et al., 2008). This decrease may either be due to continued carbon losses or the thermal acclimation of microbial communities (Karhu et al., 2014; Hartley et al., 2008). As the duration of the study may have been too short to detect changes in activity following substrate depletion, we propose a hypothesis for how an associated decrease in microbial activity may have occurred in this case. Studies on low organic carbon content $(<2 \%)$, alkaline soils, have shown that microbial communities acclimate to temperature increases via a compensatory response (Karhu et al., 2014). Due to the lack of a detectable community shift, as well as the consistent presence of putative functional potential, we propose that over a longer time period, in a natural environment where substrate would not be artificially depleted, the communities detected in this study may have undergone thermal acclimation (Kuffner et al., 2012; Karhu et al., 2014). MDV microbial communities are already adapted to the stressful oligotrophic conditions present within the Antarctic soil environment (Chan et al., 2013; Cowan et al., 2014), suggesting this adaptation may be maintained under changing nutrient conditions. Although it is also possible that changing substrate conditions may have resulted in microbial community and physiological shifts, or that communities may have switched to utilising more recalcitrant substrates, the detection of these changes is beyond the scope of the present study. Therefore, future work should focus on assessing functional changes at the cellular level, via methods such as metatranscriptomics and metaproteomics, in order to rapidly detect any temperature induced changes.

\section{Summary}

This study aimed to investigate how increased and fluctuating temperatures may affect MDV soil microbial community structure and predicted functionality on short time-scales. Using $16 \mathrm{~S}$ rRNA gene amplicon sequencing, enzymatic assays and PICRUSt functional annotation, we have shown 
that microbial community structure and both measured and predicted functionality was not significantly altered in response to short term temperature fluctuations. Soil physiochemical analysis indicated that soil characteristics were similar to those previously observed within the MDVs (Toner et al., 2013; Levy et al., 2014), as the soil was alkaline, saline and contained low levels of key nutrients such as organic carbon and nitrogen (Lee et al., 2012; Makhalanyane et al., 2013). A few dominant phyla, which typically exhibit heterotrophic physiologies and stress-tolerant lifestyles, were consistently present in all treatment groups, a finding which was complemented by results obtained from enzymatic assays and PICRUSt putative functional predictions. The lack of observed changes in community composition and functionality suggests that these communities may be resistant to short term temperature perturbations, and that there may be considerable functional redundancy within the microbial community. 


\section{Acknowledgements}

We are grateful to the National Research Foundation (NRF), the South African National Antarctic Programme (SANAP - Grant ID SNA14070974748), and the University of Pretoria (Genomics Research Institute and the Research Development Program) for funding. We also thank the New Zealand Antarctic Research Institute (NZARI) for funding and Antarctica New Zealand for field and logistics support. We wish to acknowledge Mr. M Van Goethem, Mr. R. Johnson and Dr. S. Vikram for continued laboratory and bioinformatic support.

\section{Conflict of interest}

The authors declare no conflict of interest.

\section{References}

Aislabie, J.M., Chhour, K.-L., Saul, D.J., Miyauchi, S., Ayton, J., Paetzold, R.F., Balks, M.R., 2006. Dominant bacteria in soils of Marble Point and Wright Valley, Victoria Land, Antarctica. Soil Biology and Biochemistry 38, 3041-3056.

Barrett, J.E., Virginia, R.A., Hopkins, D.W., Aislabie, J., Bargagli, R., Bockheim, J.G., Campbell, I.B., Lyons, W.B., Moorhead, D.L., Nkem, J.N., Sletten, R.S., Steltzer, H., Wall, D.H., Wallenstein, M.D., 2006. Terrestrial ecosystem processes of Victoria Land, Antarctica. Soil Biology and Biochemistry 38, 3019-3034.

Blake, L.I., Tveit, A., Øvreås, L., Head, I.M., Gray, N.D., 2015. Response of Methanogens in Arctic Sediments to Temperature and Methanogenic Substrate Availability. PLoS One 10, e0129733.

Bouyoucos, G.J., 1962. Hydrometer method improved for making particle size analysis of soils. Agronomy Journal 54, 464-465.

Bradford, M.A., Davies, C.A., Frey, S.D., Maddox, T.R., Melillo, J.M., Mohan, J.E., Reynolds, J.F., Treseder, K.K., Wallenstein, M.D., 2008. Thermal adaptation of soil microbial respiration to elevated temperature. Ecology Letters 11, 1316-1327.

Bray, R.H., Kurtz, L.T., 1945. Determination of total, organic and available forms of phosphorus in soils. Soil Science 59, 39-46. 
Bremner, J.M., Keeney, D.R., 1966. Determination and Isotope-Ratio Analysis of Different Forms of Nitrogen in Soils: 3. Exchangeable Ammonium, Nitrate, and Nitrite by Extraction-Distillation Methods. Soil Science Society of America Journal 30, 577-582.

Campbell, A.G., Schwientek, P., Vishnivetskaya, T., Woyke, T., Levy, S., Beall, C.J., Griffen, A., Leys, E., Podar, M., 2014. Diversity and genomic insights into the uncultured Chloroflexi from the human microbiota. Environmental Microbiology 16, 2635-2643.

Caporaso, J.G., Kuczynski, J., Stombaugh, J., Bittinger, K., Bushman, F.D., Costello, E.K., Fierer, N., Peña, A.G., Goodrich, J.K., Gordon, J.I., Huttley, G.A., Kelley, S.T., Knights, D., Koenig, J.E., Ley, R.E., Lozupone, C.A., McDonald, D., Muegge, B.D., Pirrung, M., Reeder, J., Sevinsky, J.R., Turnbaugh, P.J., Walters, W.A., Widmann, J., Yatsunenko, T., Zaneveld, J., Knight, R., 2010. QIIME allows analysis of high-throughput community sequencing data. Nature Methods 7, 335336.

Caporaso, J.G., Lauber, C.L., Walters, W.A., Berg-Lyons, D., Lozupone, C.A., Turnbaugh, P.J., Fierer, N., Knight, R., 2011. Global patterns of 16 S rRNA diversity at a depth of millions of sequences per sample. Proceedings of the National Academy of Sciences 108, 4516-4522.

Chan, Y., Van Nostrand, J.D., Zhou, J., Pointing, S.B., Farrell, R.L., 2013. Functional ecology of an Antarctic Dry Valley. Proceedings of the National Academy of Sciences 110, 8990-8995.

Chapman, H.D., 1965. Total exchangeable bases, Methods of soil analysis. American Society of Agronomy, Madison, Wisconsin, pp. 902-905.

Clements, C.F., Collen, B., Blackburn, T.M., Petchey, O.L., 2014. Effects of directional environmental change on extinction dynamics in experimental microbial communities are predicted by a simple model. Oikos $123,141-150$.

Coleman, N.a.G.T., 1967. The basic chemistry of soil acidity, Soil acidity and liming. American Socity of Agronomy, Madison, Wisconsin, pp. 1-41.

Cowan, D.A., Ah Tow, L., 2004. Endangered antarctic environments. Annual Review of Microbiology 58, 649-690.

Cowan, D.A., Makhalanyane, T., Dennis, P., Hopkins, D., 2014. Microbial ecology and biogeochemistry of continental Antarctic soils. Frontiers in Microbiology 5. 
Dennis, P.G., Newsham, K.K., Rushton, S.P., Ord, V.J., O'Donnell, A.G., Hopkins, D.W., 2013. Warming constrains bacterial community responses to nutrient inputs in a southern, but not northern, maritime Antarctic soil. Soil Biology and Biochemistry 57, 248-255.

DeSantis, T.Z., Hugenholtz, P., Larsen, N., Rojas, M., Brodie, E.L., Keller, K., Huber, T., Dalevi, D., Hu, P., Andersen, G.L., 2006. Greengenes, a chimera-checked 16S rRNA gene database and workbench compatible with ARB. Applied and Environmental Microbiology 72, 5069-5072.

Dreesens, L.L., Lee, C.K., Cary, S.C., 2014. The Distribution and Identity of Edaphic Fungi in the McMurdo Dry Valleys. Biology 3, 466-483.

Durall, C., Lindblad, P., 2015. Mechanisms of carbon fixation and engineering for increased carbon fixation in cyanobacteria. Algal Research 11, 263-270.

Fierer, N., Leff, J.W., Adams, B.J., Nielsen, U.N., Bates, S.T., Lauber, C.L., Owens, S., Gilbert, J.A., Wall, D.H., Caporaso, J.G., 2012. Cross-biome metagenomic analyses of soil microbial communities and their functional attributes. Proceedings of the National Academy of Sciences 109, $21390-21395$.

García-Palacios, P., Vandegehuchte, M.L., Shaw, E.A., Dam, M., Post, K.H., Ramirez, K.S., Sylvain, Z.A., Tomasel, C.M., Wall, D.H., 2015. Are there links between responses of soil microbes and ecosystem functioning to elevated $\mathrm{CO} 2, \mathrm{~N}$ deposition and warming? A global perspective. Global Change Biology 21, 1590-1600.

German, D.P., Weintraub, M.N., Grandy, A.S., Lauber, C.L., Rinkes, Z.L., Allison, S.D., 2011. Optimization of hydrolytic and oxidative enzyme methods for ecosystem studies. Soil Biology and Biochemistry 43, 1387-1397.

Gillman, G.P., Bruce, R.C., Davey, B.G., Kimble, J.M., Searle, P.L., Skjemstad, J.O., 1983. A comparison of methods used for determination of cation exchange capacity. Communications in Soil Science and Plant Analysis 14, 1005-1014.

Grenni, P., Falconi, F., Caracciolo, A.B., 2012. Microcosm experiments for evaluating natural bioremediation of contaminated ecosystems. Chemical Engineering 28, 7-12. 
Gutknecht, J.L., Field, C.B., Balser, T.C., 2012. Microbial communities and their responses to simulated global change fluctuate greatly over multiple years. Global Change Biology 18, 22562269.

Hammer, Ø., Harper, D.A.T., Ryan, P.D., 2004. PAST: paleontological statistics software package for education and data analysis. Palaeontologia Electronica 4.

Hartley, I.P., Hopkins, D.W., Garnett, M.H., Sommerkorn, M., Wookey, P.A., 2008. Soil microbial respiration in arctic soil does not acclimate to temperature. Ecology Letters 11, 1092-1100.

Hill, R., Saetnan, E.R., Scullion, J., Gwynn-Jones, D., Ostle, N., Edwards, A., 2015. Temporal and spatial influences incur reconfiguration of Arctic heathland soil bacterial community structure. Environmental Microbiology.

Hopkins, D.W., Sparrow, A.D., Elberling, B., Gregorich, E.G., Novis, P.M., Greenfield, L.G., Tilston, E.L., 2006. Carbon, nitrogen and temperature controls on microbial activity in soils from an Antarctic dry valley. Soil Biology and Biochemistry 38, 3130-3140.

Hopkins, D.W., Sparrow, A.D., Shillam, L.L., English, L.C., Dennis, P.G., Novis, P., Elberling, B., Gregorich, E.G., Greenfield, L.G., 2008. Enzymatic activities and microbial communities in an Antarctic dry valley soil: Responses to $\mathrm{C}$ and $\mathrm{N}$ supplementation. Soil Biology and Biochemistry 40, 2130-2136.

Imam, S., Noguera, D.R., Donohue, T.J., 2015. CceR and AkgR regulate central carbon and energy metabolism in Alphaproteobacteria. mBio 6, e02461-02414.

IPCC, 2007. Climate Change 2007: Impacts, Adaptation and Vulnerability, In: Parry ML, C.O., Palutikof JP, Van der Linden PJ, Hanson CE (Ed.), Contribution of a Working Group II to the Fourth Assessment Report of the Intergovernmental Panel on Climate Change, Cambridge, pp. 8182.

Isbell, F., Craven, D., Connolly, J., Loreau, M., Schmid, B., Beierkuhnlein, C., Bezemer, T.M., Bonin, C., Bruelheide, H., de Luca, E., Ebeling, A., Griffin, J.N., Guo, Q., Hautier, Y., Hector, A., Jentsch, A., Kreyling, J., Lanta, V., Manning, P., Meyer, S.T., Mori, A.S., Naeem, S., Niklaus, P.A., Polley, H.W., Reich, P.B., Roscher, C., Seabloom, E.W., Smith, M.D., Thakur, M.P., Tilman, D., Tracy, B.F., van der Putten, W.H., van Ruijven, J., Weigelt, A., Weisser, W.W., Wilsey, B., 
Eisenhauer, N., 2015. Biodiversity increases the resistance of ecosystem productivity to climate extremes. Nature advanced online publication.

Jefferies, R.L., Walker, N.A., Edwards, K.A., Dainty, J., 2010. Is the decline of soil microbial biomass in late winter coupled to changes in the physical state of cold soils? Soil Biology and Biochemistry 42, 129-135.

Jung, J., Yeom, J., Kim, J., Han, J., Lim, H.S., Park, H., Hyun, S., Park, W., 2011. Change in gene abundance in the nitrogen biogeochemical cycle with temperature and nitrogen addition in Antarctic soils. Research in Microbiology 162, 1018-1026.

Kanehisa, M., Goto, S., 2000. KEGG: kyoto encyclopedia of genes and genomes. Nucleic Acids Research 28, 27-30.

Kanehisa, M., Goto, S., Sato, Y., Kawashima, M., Furumichi, M., Tanabe, M., 2014. Data, information, knowledge and principle: back to metabolism in KEGG. Nucleic Acids Research 42, D199-205.

Karhu, K., Auffret, M.D., Dungait, J.A., Hopkins, D.W., Prosser, J.I., Singh, B.K., Subke, J.-A., Wookey, P.A., Ågren, G.I., Sebastià, M.-T., 2014. Temperature sensitivity of soil respiration rates enhanced by microbial community response. Nature $513,81-84$.

Kuffner, M., Hai, B., Rattei, T., Melodelima, C., Schloter, M., Zechmeister-Boltenstern, S., Jandl, R., Schindlbacher, A., Sessitsch, A., 2012. Effects of season and experimental warming on the bacterial community in a temperate mountain forest soil assessed by 16S rRNA gene pyrosequencing. FEMS Microbiology Ecology 82, 551-562.

Langille, M.G.I., Zaneveld, J., Caporaso, J.G., McDonald, D., Knights, D., Reyes, J.A., Clemente, J.C., Burkepile, D.E., Vega Thurber, R.L., Knight, R., Beiko, R.G., Huttenhower, C., 2013. Predictive functional profiling of microbial communities using 16S rRNA marker gene sequences. Nature Biotechnology 31, 814-821.

Laudicina, V.A., Benhua, S., Dennis, P.G., Badalucco, L., Rushton, S.P., Newsham, K.K., O'Donnell, A.G., Hartley, I.P., Hopkins, D.W., 2015. Responses to increases in temperature of heterotrophic micro-organisms in soils from the maritime Antarctic. Polar Biology, 1-8. 
Lee, C.K., Barbier, B.A., Bottos, E.M., McDonald, I.R., Cary, S.C., 2012. The Inter-Valley Soil Comparative Survey: the ecology of Dry Valley edaphic microbial communities. The ISME Journal 6, 1046-1057.

Levy, J.S., Fountain, A.G., Gooseff, M.N., Barrett, J.E., Vantreese, R., Welch, K.A., Lyons, W.B., Nielsen, U.N., Wall, D.H., 2014. Water track modification of soil ecosystems in the Lake Hoare basin, Taylor Valley, Antarctica. Antarctic Science 26, 153-162.

Makhalanyane, T.P., Valverde, A., Birkeland, N.-K., Cary, S.C., Tuffin, I.M., Cowan, D.A., 2013. Evidence for successional development in Antarctic hypolithic bacterial communities. The ISME Journal 7, 2080-2090.

Makhalanyane TP, Valverde A, Velázquez D, Gunnigle E, Van Goethem MW, Quesada A et al (2015). Ecology and biogeochemistry of cyanobacteria in soils, permafrost, aquatic and cryptic polar habitats. Biodiversity and Conservation 24: 819-840.

Margulis, L., Chapman, M.J., 2009. Kingdom Prokaryotae (Bacteria, Monera, Prokarya), Kingdoms and Domains: An Illustrated Guide to the Phyla of Life on Earth. Elsevier Science, New York, pp. $35-108$

Martínez, A., Larrañaga, A., Pérez, J., Descals, E., Pozo, J., 2014. Temperature affects leaf litter decomposition in low-order forest streams: field and microcosm approaches. FEMS Microbiology Ecology 87, 257-267.

Melle, C., Wallenstein, M., Darrouzet-Nardi, A., Weintraub, M.N., 2015. Microbial activity is not always limited by nitrogen in Arctic tundra soils. Soil Biology and Biochemistry 90, 52-61.

Newsham, K.K., Hopkins, D.W., Carvalhais, L.C., Fretwell, P.T., Rushton, S.P., Odonnell, A.G., Dennis, P.G., 2015. Relationship between soil fungal diversity and temperature in the maritime Antarctic. Nature Climate Change advanced online publication.

Niederberger, T.D., McDonald, I.R., Hacker, A.L., Soo, R.M., Barrett, J.E., Wall, D.H., Cary, S.C., 2008. Microbial community composition in soils of Northern Victoria Land, Antarctica. Environmental Microbiology 10, 1713-1724.

Okie, J.G., Van Horn, D.J., Storch, D., Barrett, J.E., Gooseff, M.N., Kopsova, L., Takacs-Vesbach, C.D., 2015. Niche and metabolic principles explain patterns of diversity and distribution: theory and 
a case study with soil bacterial communities. Proceedings of the Royal Society of London B: Biological Sciences 282.

Oren, A., Papke, R.T., 2010. The Phyla of Prokaryotes Cultured and Unclultured, Molecular Phylogeny of Microorganisms. Caister Academic Press, Norfolk, UK, pp. 85-107.

Pearce, D.A., Newsham, K.K., Thorne, M.A., Calvo-Bado, L., Krsek, M., Laskaris, P., Hodson, A., Wellington, E.M., 2012. Metagenomic analysis of a southern maritime antarctic soil. Frontiers in Microbiology 3, 403.

Pessi, I.S., de Oliveira Elias, S., Simões, F.L., Simões, J.C., Macedo, A.J., 2012. Functional diversity of microbial communities in soils in the vicinity of Wanda Glacier, Antarctic Peninsula. Microbes and Environments 27, 200.

Philippot, L., Spor, A., Henault, C., Bru, D., Bizouard, F., Jones, C.M., Sarr, A., Maron, P.-A., 2013. Loss in microbial diversity affects nitrogen cycling in soil. The ISME Journal 7, 1609-1619.

Pointing, S.B., Chan, Y., Lacap, D.C., Lau, M.C.Y., Jurgens, J.A., Farrell, R.L., 2009. Highly specialized microbial diversity in hyper-arid polar desert. Proceedings of the National Academy of Sciences 106, 19964-19969.

Pold, G., DeAngelis, K.M., 2013. Up against the wall: the effects of climate warming on soil microbial diversity and the potential for feedbacks to the carbon cycle. Diversity $5,409-425$.

Richter, I., Herbold, C.W., Lee, C.K., McDonald, I.R., Barrett, J.E., Cary, S.C., 2014. Influence of soil properties on archaeal diversity and distribution in the McMurdo Dry Valleys, Antarctica. FEMS Microbiology Ecology 89, 347-359.

Rinnan, R., Rousk, J., Yergeau, E., Kowalchuk, G.A., Bååth, E., 2009. Temperature adaptation of soil bacterial communities along an Antarctic climate gradient: predicting responses to climate warming. Global Change Biology 15, 2615-2625.

Schindlbacher, A., Rodler, A., Kuffner, M., Kitzler, B., Sessitsch, A., Zechmeister-Boltenstern, S., 2011. Experimental warming effects on the microbial community of a temperate mountain forest soil. Soil Biology and Biochemistry 43, 1417-1425. 
Seo, J., Jang, I., Jung, J.Y., Lee, Y.K., Kang, H., 2015. Warming and increased precipitation enhance phenol oxidase activity in soil while warming induces drought stress in vegetation of an Arctic ecosystem. Geoderma 259-260, 347-353.

Shivlata, L., Tulasi, S., 2015. Thermophilic and alkaliphilic Actinobacteria: Biology and potential applications. Frontiers in Microbiology 6.

Singh, B.K., Bardgett, R.D., Smith, P., Reay, D.S., 2010. Microorganisms and climate change: terrestrial feedbacks and mitigation options. Nature Reviews Microbiology 8, 779-790.

Sinsabaugh, R.L., Lauber, C.L., Weintraub, M.N., Ahmed, B., Allison, S.D., Crenshaw, C., Contosta, A.R., Cusack, D., Frey, S., Gallo, M.E., Gartner, T.B., Hobbie, S.E., Holland, K., Keeler, B.L., Powers, J.S., Stursova, M., Takacs-Vesbach, C., Waldrop, M.P., Wallenstein, M.D., Zak, D.R., Zeglin, L.H., 2008. Stoichiometry of soil enzyme activity at global scale. Ecology Letters 11, $1252-1264$.

Sinsabaugh, R.S., 1994. Enzymic analysis of microbial pattern and process. Biology and Fertility of Soils $17,69-74$.

Sokol, E.R., Herbold, C.W., Lee, C.K., Cary, S.C., Barrett, J., 2013. Local and regional influences over soil microbial metacommunities in the Transantarctic Mountains. Ecosphere 4, 1-24.

Song, M., Jiang, J., Cao, G., Xu, X., 2010. Effects of temperature, glucose and inorganic nitrogen inputs on carbon mineralization in a Tibetan alpine meadow soil. European Journal of Soil Biology $46,375-380$.

Stomeo, F., Makhalanyane, T.P., Valverde, A., Pointing, S.B., Stevens, M.I., Cary, C.S., Tuffin, M.I., Cowan, D.A., 2012. Abiotic factors influence microbial diversity in permanently cold soil horizons of a maritime-associated Antarctic Dry Valley. FEMS Microbiology Ecology 82, 326-340. Team, R.C., 2013. R: A Language and Environment for Statistical Computing. R Foundation for Statistical Computing, Vienna, Austria.

Teixeira, L.C., Peixoto, R.S., Cury, J.C., Sul, W.J., Pellizari, V.H., Tiedje, J., Rosado, A.S., 2010. Bacterial diversity in rhizosphere soil from Antarctic vascular plants of Admiralty Bay, maritime Antarctica. The ISME Journal 4, 989-1001. 
Thiel, V., Tomsho, L.P., Burhans, R., Gay, S.E., Schuster, S.C., Ward, D.M., Bryant, D.A., 2015. Draft genome sequence of the Deinococcus-Thermus bacterium Meiothermus ruber strain $A$. Genome announcements 3, e00202-00215.

Tiao, G., Lee, C.K., McDonald, I.R., Cowan, D.A., Cary, S.C., 2012. Rapid microbial response to the presence of an ancient relic in the Antarctic Dry Valleys. Nature Communications 3, 660.

Toner, J.D., Sletten, R.S., Prentice, M.L., 2013. Soluble salt accumulations in Taylor Valley, Antarctica: Implications for paleolakes and Ross Sea Ice Sheet dynamics. Journal of Geophysical Research: Earth Surface 118, 198-215.

Treonis, A.M., Wall, D.H., Virginia, R.A., 2002. Field and microcosm studies of decomposition and soil biota in a cold desert soil. Ecosystems 5, 159-170.

Walkley, A., Black, I.A., 1934. An examination of Degtjareff method for determining soil organic matter, and proposed modification of the chromic acid tritation method. Soil Science 37, 29-38.

Wallenstein, M.D., McMahon, S.K., Schimel, J.P., 2009. Seasonal variation in enzyme activities and temperature sensitivities in Arctic tundra soils. Global Change Biology 15, 1631-1639.

Wang, N.F., Zhang, T., Zhang, F., Wang, E.T., He, J.F., Ding, H., Zhang, B.T., Liu, J., Ran, X.B., Zang, J.Y., 2015. Diversity and structure of soil bacterial communities in the Fildes Region (maritime Antarctica) as revealed by 454 pyrosequencing. Frontiers in Microbiology 6.

Wynn-Williams, D., 1996. Response of pioneer soil microalgal colonists to environmental change in Antarctica. Microbial Ecology 31, 177-188.

Xu, Z., Malmer, D., Langille, M.G., Way, S.F., Knight, R., 2014. Which is more important for classifying microbial communities: who's there or what they can do\&quest. The ISME Journal.

Yergeau, E., Bokhorst, S., Kang, S., Zhou, J., Greer, C.W., Aerts, R., Kowalchuk, G.A., 2012. Shifts in soil microorganisms in response to warming are consistent across a range of Antarctic environments. The ISME Journal 6, 692-702.

Yergeau, E., Kang, S., He, Z., Zhou, J., Kowalchuk, G.A., 2007a. Functional microarray analysis of nitrogen and carbon cycling genes across an Antarctic latitudinal transect. The ISME Journal 1 , 163-179. 
Yergeau, E., Kowalchuk, G.A., 2008. Responses of Antarctic soil microbial communities and associated functions to temperature and freeze-thaw cycle frequency. Environmental Microbiology $10,2223-2235$.

Yergeau, E., Newsham, K.K., Pearce, D.A., Kowalchuk, G.A., 2007b. Patterns of bacterial diversity across a range of Antarctic terrestrial habitats. Environmental Microbiology 9, 2670-2682.

Zogg, G.P., Zak, D.R., Ringelberg, D.B., White, D.C., MacDonald, N.W., Pregitzer, K.S., 1997. Compositional and functional shifts in microbial communities due to soil warming. Soil Science Society of America Journal 61, 475-481. 


\section{List of Tables:}

Table 1: Soil characteristics identified from soil physiochemical analyses of pre-treatment samples.

Table 2: Measures of $\alpha-\beta$ - and $\gamma$ - diversity for temperature treatment samples taken at several time-points.

Table 3: Pathways, their associated cellular processes and marker genes identified from PICRUSt and KEGG orthology using 16S rRNA gene sequencing data.

Table 4: Soil extracellular enzymes analysed and their corresponding functions.

\section{List of Figures:}

Figure 1: Collection location of soil samples from the Taylor Valley, McMurdo Dry Valleys, Antarctica.

Figure 2: A two-dimensional (2D) non-metric multidimensional scaling (NMDS) plot of samples according to OTU abundance generated using Bray Curtis similarity. The samples are plotted according to treatment or temperature, with the key indicated in the top left corner of the graph. Control, fluctuating and stable refer to the three treatment groups. Note the $2 \mathrm{D}$ stress at 0,117 .

Figure 3: Phylum level taxonomic classification of samples according to temperature treatment groups. Samples are indicated on the $y$-axis where control, fluctuating and stable refer to the three temperature treatment groups at $0^{\circ} \mathrm{C}, 0-15-0^{\circ} \mathrm{C}$ and $15^{\circ} \mathrm{C}$ respectively. The $\mathrm{x}$-axis indicates percentage abundances of each phylum within the three treatment groups.

Figure 4: Phylum level taxonomic classification of samples according to sampling day. Abundance of each phylum is indicated with percentages on the $y$-axis. The $x$-axis refers to sampling days where -10 is ten days prior to the start of the microcosm experiment and 0 is the start of the experiment.

Figure 5: Heatmap of KEGG pathway assignment to $16 \mathrm{~S}$ rRNA gene amplicon sequencing data using PICRUSt. Pathways highlighted with a red box were identified as most relevant to this study. $\mathrm{C}, \mathrm{F}$ and $\mathrm{S}$ refer to the three temperature treatment groups control, fluctuating and stable, respectively. Numbers -10 to 30 indicate days at which samples were taken during the microcosm temperature experiment.

Figure 6: Potential activities of four extracellular enzymes measured during the microcosm experiment for three temperature treatment groups. (A) Phenol oxidase, (B) Phenol peroxidase, (C) Alkaline phosphatase, (D) Leucine aminopeptidase. Bar plots show the mean of three technical 
replicates; error bars represent the standard error. Only four of the seven enzymes analysed are present as the remaining three showed no activity in all samples.

Figure 7: A redundancy analysis (RDA) ordination of phylogenetic data with extracellular enzymes added as vectors indicating significant drivers of the observed clustering ( $p$-value $<0.05$ ). The three treatment groups are indicated by the key in the top left corner. LAP and PO refer to two enzymes, namely leucine aminopeptidase and phenol oxidase, respectively.

\section{Supplementary Information}

\section{List of Supplementary Tables:}

Table S1: Gamma-diversity of temperature treatment samples according to sampling day.

\section{List of Supplementary Figures:}

Figure S1: Line chart indicating the experimental design of the microcosm experiment. The experiment was conducted over a 30-day period, with the start indicated at day 0 . Day -10 refers to a period of 10 days prior to the start of the experiment. The three treatment groups and their temperatures at specific time-points are indicated.

Figure S2: Soil microcosms for the three temperature treatment groups. (A) Control group, (B) Fluctuating group and (C) Stable group.

Figure S3: Abundance of the phylum Deinococcus-Thermus summarised to class level across three treatment groups and eight sampling points indicated in percentages. Only one class, Deinococci, was identified. The three different temperature treatment groups are shown by $\mathrm{C}, \mathrm{F}$ and $\mathrm{S}$ which represent control $\left(0^{\circ} \mathrm{C}\right)$, fluctuating $\left(0^{\circ} \mathrm{C}-15^{\circ} \mathrm{C}\right)$ and stable $\left(15^{\circ} \mathrm{C}\right)$ respectively. Numbers -10 to 30 indicate the sampling days, where day 0 is the start of the temperature experiment and day -10 is ten days prior to the start.

Figure S4: Abundance of the phylum Actinobacteria summarised to class level across three treatment groups and eight sampling points indicated in percentages. The three different temperature treatment groups are shown by $\mathrm{C}, \mathrm{F}$ and $\mathrm{S}$ which represent control $\left(0^{\circ} \mathrm{C}\right)$, fluctuating $\left(0^{\circ} \mathrm{C}-15^{\circ} \mathrm{C}\right)$ and stable $\left(15^{\circ} \mathrm{C}\right)$ respectively. Numbers -10 to 30 indicate the sampling days, where day 0 is the start of the temperature experiment and day -10 is ten days prior to the start.

Figure S5: Abundance of the phylum Chloroflexi summarised to class level across three treatment groups and eight sampling points indicated in percentages. The three different temperature treatment groups are shown by $\mathrm{C}, \mathrm{F}$ and $\mathrm{S}$ which represent control $\left(0^{\circ} \mathrm{C}\right)$, fluctuating $\left(0^{\circ} \mathrm{C}-15^{\circ} \mathrm{C}\right)$ 
and stable $\left(15^{\circ} \mathrm{C}\right)$ respectively. Numbers -10 to 30 indicate the sampling days, where day 0 is the start of the temperature experiment and day -10 is ten days prior to the start. 
Table 1: Soil characteristics identified from soil physiochemical analyses of pre-treatment samples.

\begin{tabular}{ll}
\hline Soil Characteristics & Pooled replicates \\
\hline Percentage sand & $97( \pm 0.42)$ \\
Percentage silt & $1( \pm 0)$ \\
Percentage clay & $2( \pm 0)$ \\
Percentage carbon & $0.0935( \pm 0.009)$ \\
$\mathrm{pH}$ & $9.9( \pm 0.015)$ \\
$\mathrm{Cation}$ exchange capacity $(\mathrm{cmol} / \mathrm{kg})$ & $8.29( \pm 1.3)$ \\
$\mathrm{NH}_{4}$ and $\mathrm{NO}_{3}(\mathrm{ppm})$ & $11.55( \pm 0.39)$ \\
$\mathrm{K}(\mathrm{ppm})$ & $70.89( \pm 16.6)$ \\
$\mathrm{Ca}(\mathrm{ppm})$ & $110.94( \pm 23.4)$ \\
$\mathrm{Na}(\mathrm{ppm})$ & $127.41( \pm 13.8)$ \\
$\mathrm{Mg}(\mathrm{ppm})$ & $17.42( \pm 3.4)$ \\
$\mathrm{P}(\mathrm{ppm})$ & $7.69( \pm 0.2)$ \\
\hline
\end{tabular}

The values were obtained from soil analysed prior to the microcosm experiment and are reported as a mean of three replicates. Standard deviations for each analysis are indicated in brackets. 
Table 2: Measures of $\alpha-\beta$ - and $\gamma$ - diversity for temperature treatment samples taken at several time-points.

\begin{tabular}{|c|c|c|c|c|}
\hline \multirow[b]{2}{*}{ Samples } & \multicolumn{2}{|r|}{ a-diversity } & \multirow{2}{*}{$\begin{array}{l}\beta \text {-diversity } \\
\text { Whittaker }\end{array}$} & \multirow{2}{*}{$\mathrm{Y}$-diversity } \\
\hline & $\begin{array}{l}\text { Observed } \\
\text { OTUs }\end{array}$ & Shannon diversity $\left(\mathrm{H}^{\prime}\right)$ & & \\
\hline C-10 & 1556 & 5,232013 & 2,926735 & \\
\hline $\mathrm{CO}$ & 1307 & 5,311446 & 3,484315 & \\
\hline C5 & 1411 & 5,152953 & 3,227498 & \\
\hline $\mathrm{C} 10$ & 761 & 5,162895 & 5,984231 & \\
\hline C15 & 776 & 4,953165 & 5,868557 & \\
\hline $\mathrm{C} 20$ & 569 & 4,715299 & 8,003515 & \\
\hline C25 & 581 & 4,665257 & 7,83821 & \\
\hline C30 & 1071 & 4,674236 & 4,252101 & \\
\hline Control mean & 1004 & 4,983408 & 5,198145 & 4554 \\
\hline $\mathrm{F}-10$ & 1424 & 4,99119 & 2,752809 & \\
\hline F0 & 711 & 4,955225 & 5,513361 & \\
\hline F5 & 997 & 4,931967 & 3,931795 & \\
\hline F10 & 524 & 4,830524 & 7,480916 & \\
\hline F15 & 1022 & 4,933382 & 3,835616 & \\
\hline $\mathrm{F} 20$ & 439 & 4,632857 & 8,929385 & \\
\hline F25 & 969 & 5,097072 & 4,045408 & \\
\hline F30 & 945 & 4,711199 & 4,148148 & \\
\hline Fluctuating mean & 879 & 4,885427 & 5,07968 & 3920 \\
\hline S-10 & 1166 & 4,924196 & 3,105489 & \\
\hline So & 1258 & 5,265043 & 2,878378 & \\
\hline S5 & 602 & 4,826812 & 6,01495 & \\
\hline S10 & 379 & 4,589837 & 9,55409 & \\
\hline S15 & 866 & 5,140891 & 4,181293 & \\
\hline S20 & 553 & 4,896036 & 6,54792 & \\
\hline S25 & 921 & 4,99164 & 3,931596 & \\
\hline S30 & 859 & 4,757152 & 4,215367 & \\
\hline Stable mean & 826 & 4,923951 & 5,053635 & 3621 \\
\hline
\end{tabular}

$\mathrm{C}, \mathrm{F}$ and $\mathrm{S}$ refer to the control, fluctuating and stable temperature treatment groups, respectively. Numbers $(-10$ to 30 ) indicate the days samples were taken throughout the microcosm temperature experiment. 
Table 3: Pathways, their associated cellular processes and marker genes identified from PICRUSt and KEGG orthology using 16S rRNA gene sequencing data

\begin{tabular}{|c|c|c|}
\hline Pathway & Cellular process(es) involved & Marker gene(s) identified \\
\hline $\begin{array}{l}\text { Replication and } \\
\text { repair }\end{array}$ & $\begin{array}{l}\text { Replication and repair of damaged DNA - base } \\
\text { excision repair, homologous recombination, } \\
\text { nucleotide excision repair }\end{array}$ & $\begin{array}{l}\text { Base excision repair (alkA - glycosylase, xthA - } \\
\text { exodeoxyribonuclease, pol } A \text { - DNA polymerase I) * }\end{array}$ \\
\hline $\begin{array}{l}\text { Environmental } \\
\text { Adaptation }\end{array}$ & $\begin{array}{l}\text { Transcription factors involved in stress response } \\
\text { as well as cold and heat adaptation }\end{array}$ & $\begin{array}{l}\text { Adaptive stress response (transcriptional regulators } \\
\text { - ada-alk, adaA, ada), cold shock protein (cspA), } \\
\text { heat and stress response (transcription factor - } \\
\text { cts } R)^{\star}\end{array}$ \\
\hline $\begin{array}{l}\text { Energy } \\
\text { metabolism }\end{array}$ & $\begin{array}{l}\text { Carbon fixation, photosynthesis, as well as } \\
\text { nitrogen and methane metabolism }\end{array}$ & $\begin{array}{l}\text { Carbon fixation (RuBisCo }-r b c l, r b c s, p p c) \text {, nitrogen } \\
\text { fixation (nitrogenase - nifH, anfG), ammonification } \\
\text { (nitrate reductase- nirK) and denitrification (nitrite } \\
\text { reductase - nirB) }\end{array}$ \\
\hline $\begin{array}{l}\text { Carbohydrate } \\
\text { metabolism }\end{array}$ & $\begin{array}{l}\text { Nucleotide and sugar metabolism, such as } \\
\text { fructose, glucose and mannose metabolism. }\end{array}$ & 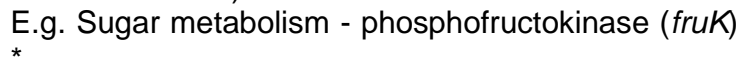 \\
\hline $\begin{array}{l}\text { Amino acid } \\
\text { metabolism }\end{array}$ & $\begin{array}{l}\text { Biosynthesis and degradation of amino acids. } \\
\text { Including both hydrophobic amino acids (such as } \\
\text { glycine, leucine, isoleucine), and polar/ } \\
\text { hydrophilic amino acids (such as lysine, arginine } \\
\text { and aspartate). }\end{array}$ & $\begin{array}{l}\text { E.g Amino acid synthesis (patA - aminotransferase), } \\
\text { amino acid degradation (icuD - dehydrogenase) * }\end{array}$ \\
\hline
\end{tabular}

${ }^{*}$ Not all possible marker genes for all pathways are indicated, as not all were determined in the analysis.

Relevant genes for several pathways are indicated with their associated function. 
Table 4: Soil extracellular enzymes analysed and their corresponding functions.

\begin{tabular}{|c|c|c|}
\hline Extracellular enzyme & Abbreviation & Function \\
\hline$\beta$-Xylosidase & $\mathrm{BX}$ & $\begin{array}{l}\text { Degradation of hemicellulose; aids in microbial acquisition of } \\
\text { carbon }\end{array}$ \\
\hline$\beta$-Glucosidase & $B G$ & Degradation of cellulose; aids in microbial acquisition of carbon \\
\hline $\begin{array}{l}\beta-N \text {-acetyl- } \\
\text { glucosaminidase }\end{array}$ & NAG & $\begin{array}{l}\text { Degradation of } \beta-1,4 \text {-linked glucosamine polymers such as } \\
\text { chitin; aids in microbial acquisition of nitrogen }\end{array}$ \\
\hline $\begin{array}{l}\text { Leucine } \\
\text { aminopeptidase }\end{array}$ & LAP & $\begin{array}{l}\text { Removal of hydrophobic amino acids from peptides; aids in } \\
\text { microbial acquisition of nitrogen }\end{array}$ \\
\hline Alkaline phosphatase & $\mathrm{AP}$ & $\begin{array}{l}\text { Degradation of phosphomono- and di-esters; aids in microbial } \\
\text { acquisition of phosphorus }\end{array}$ \\
\hline Phenol oxidase & $\mathrm{PO}$ & $\begin{array}{l}\text { Polyphenol oxidation or lignin degradation; aids in microbial } \\
\text { nutrient acquisition }\end{array}$ \\
\hline Phenol peroxidase & PPO & $\begin{array}{l}\text { Degradation of lignin and aromatic compounds; aids in microbial } \\
\text { nutrient acquisition }\end{array}$ \\
\hline
\end{tabular}


Figure 1

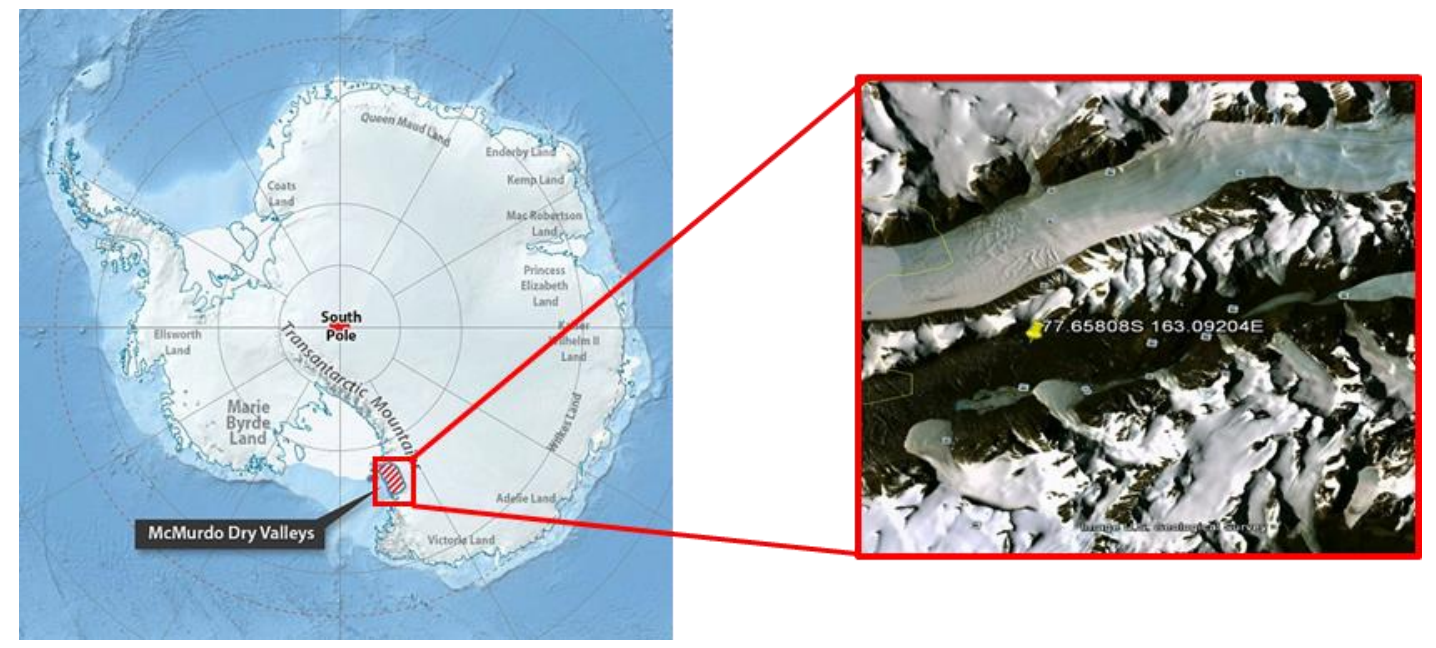




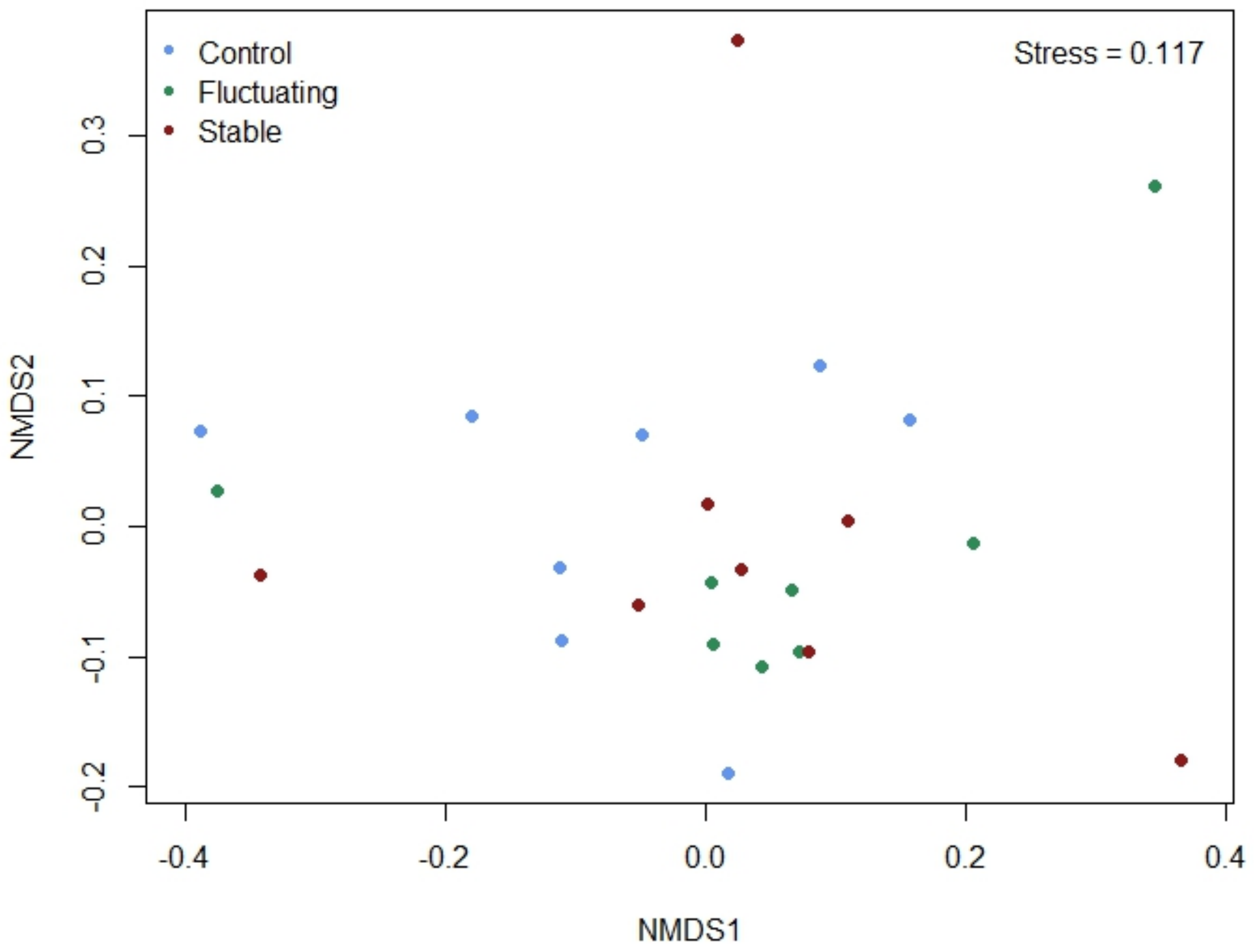




\section{Phylum level classification by treatment}

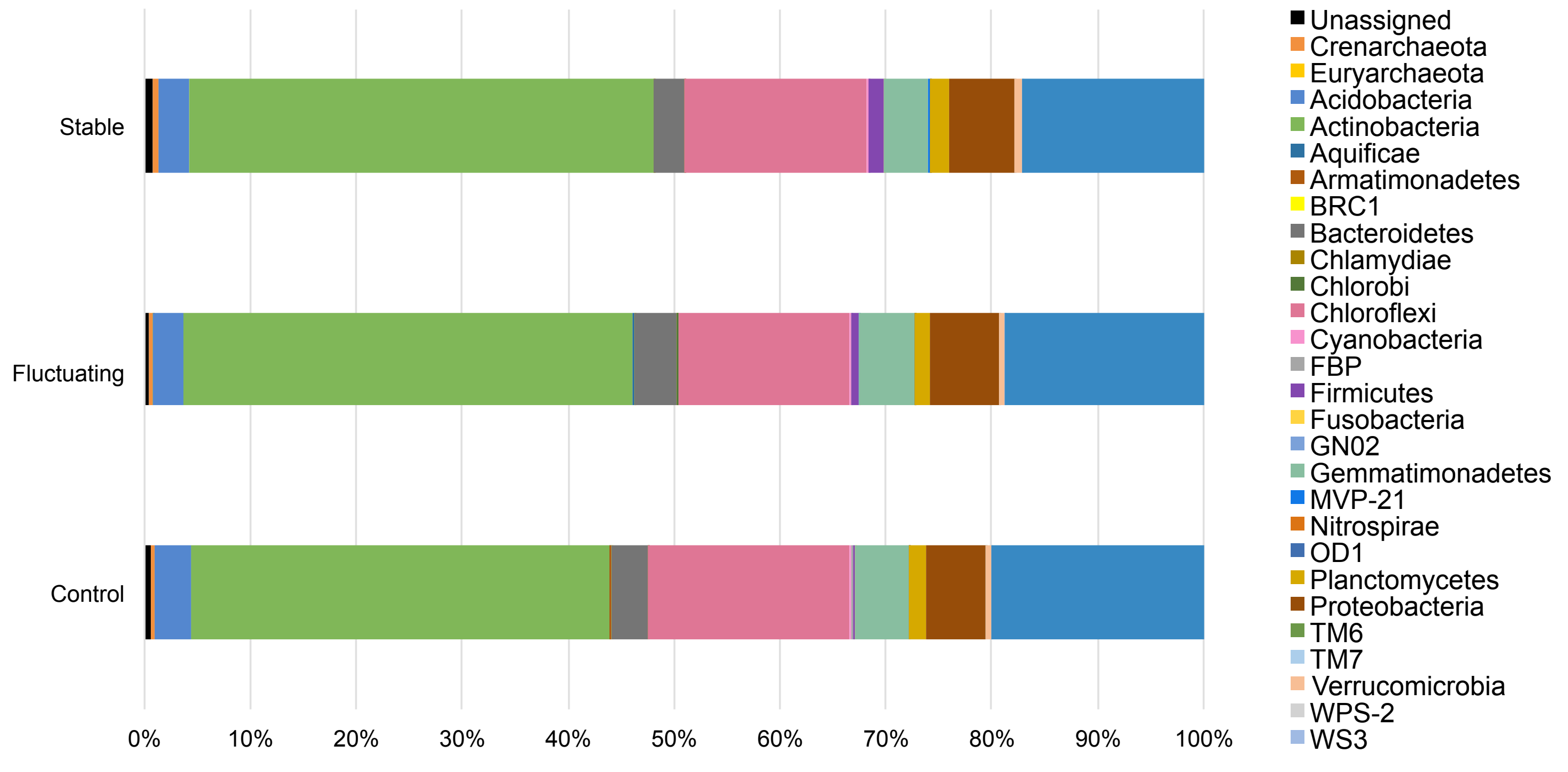




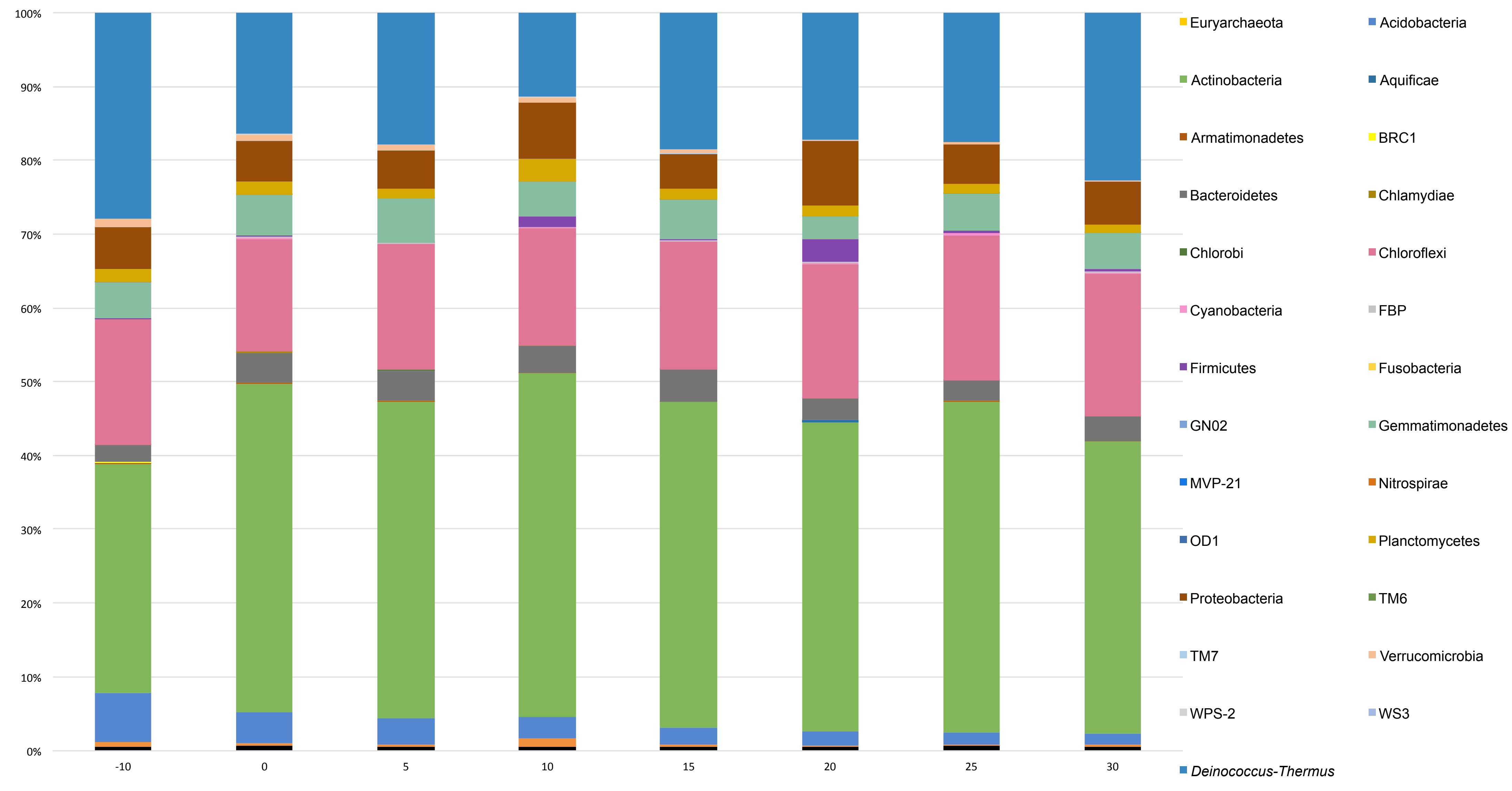




\section{Figure 5}

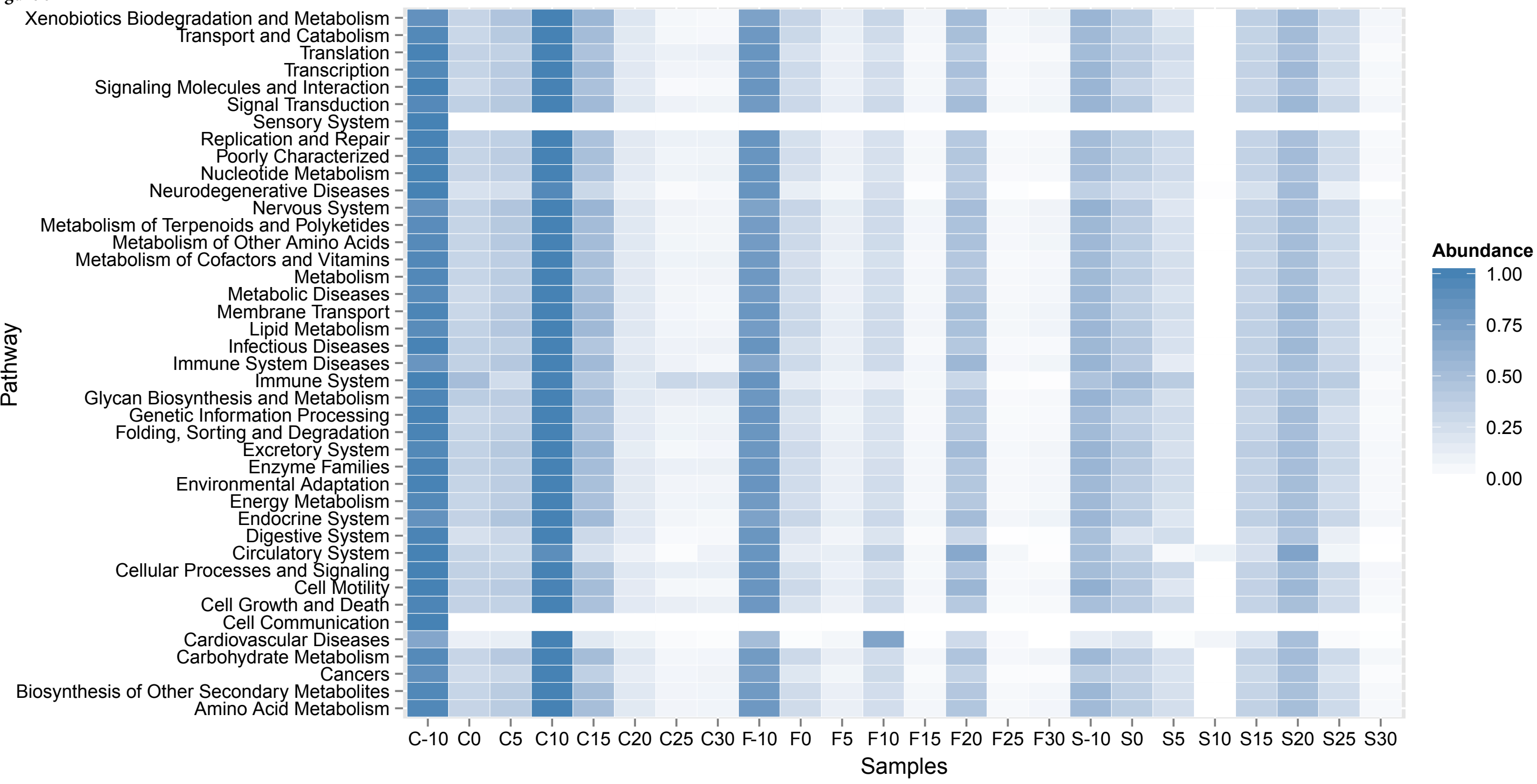


A) Phenol Oxidase

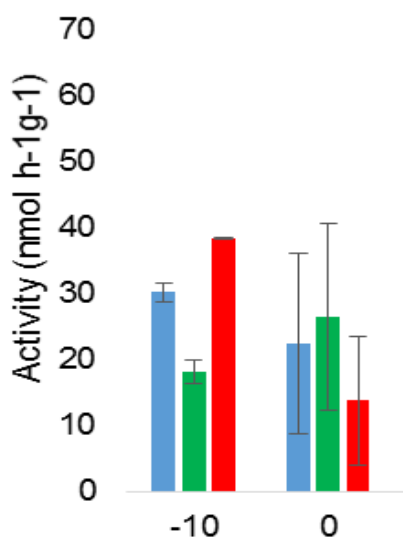

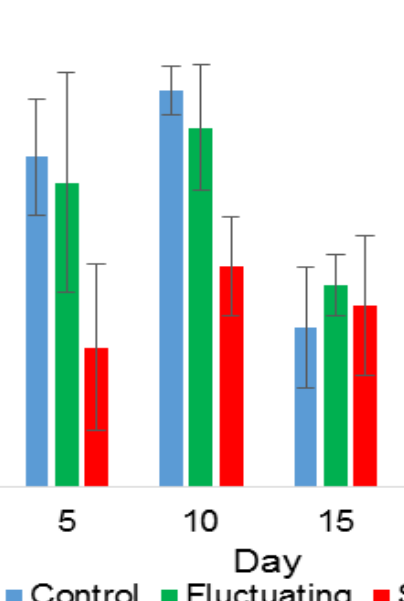

- Control $=$ Fluctuating $=$ Stable

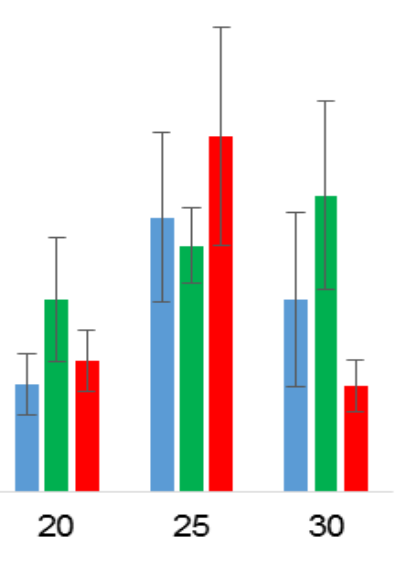

30

C) Alkaline Phosphatase

8



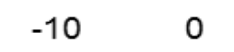

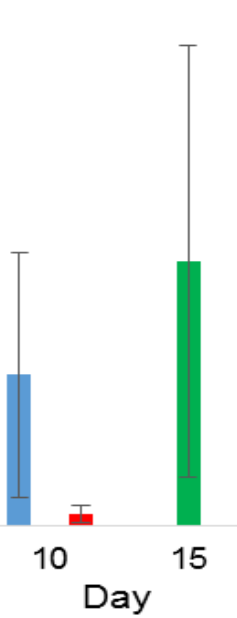

Day

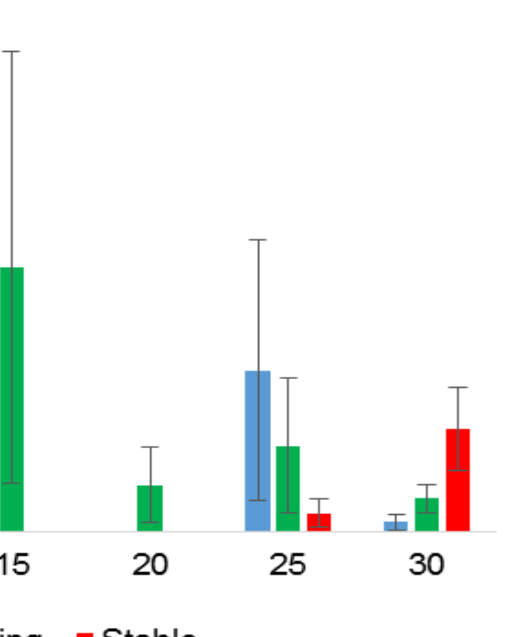

$\because$ Stable
70

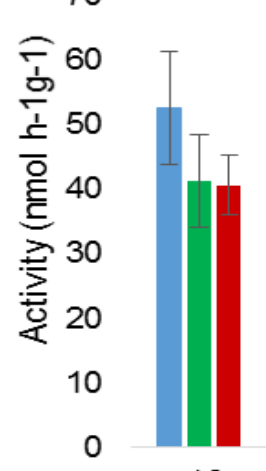

$-10$
B) Phenol Peroxidase
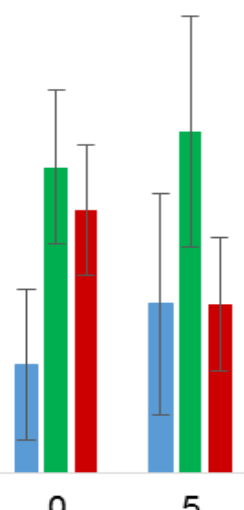

5 -Control = Fluctuating -Stable

D) Leucine Aminopeptidase

0,9

$\widehat{F}^{0,8}$

흔 0,7

亡 0,6

을 0,5

논, 0,4

褯 0,3

0,2

0,1

0

$-10$
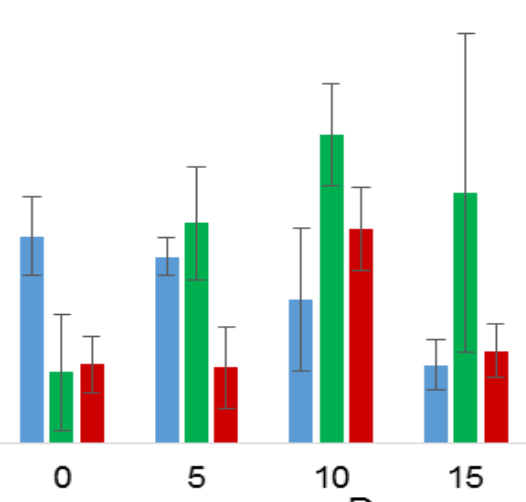

Day

15

- Control $\square$ Fluctuating $\square$ Stable

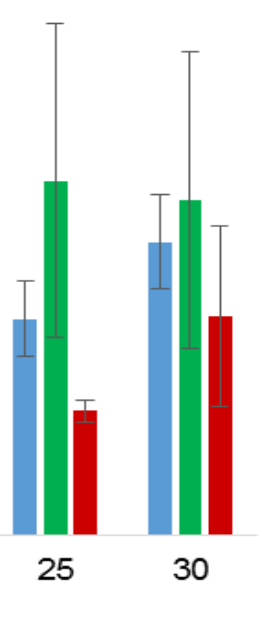




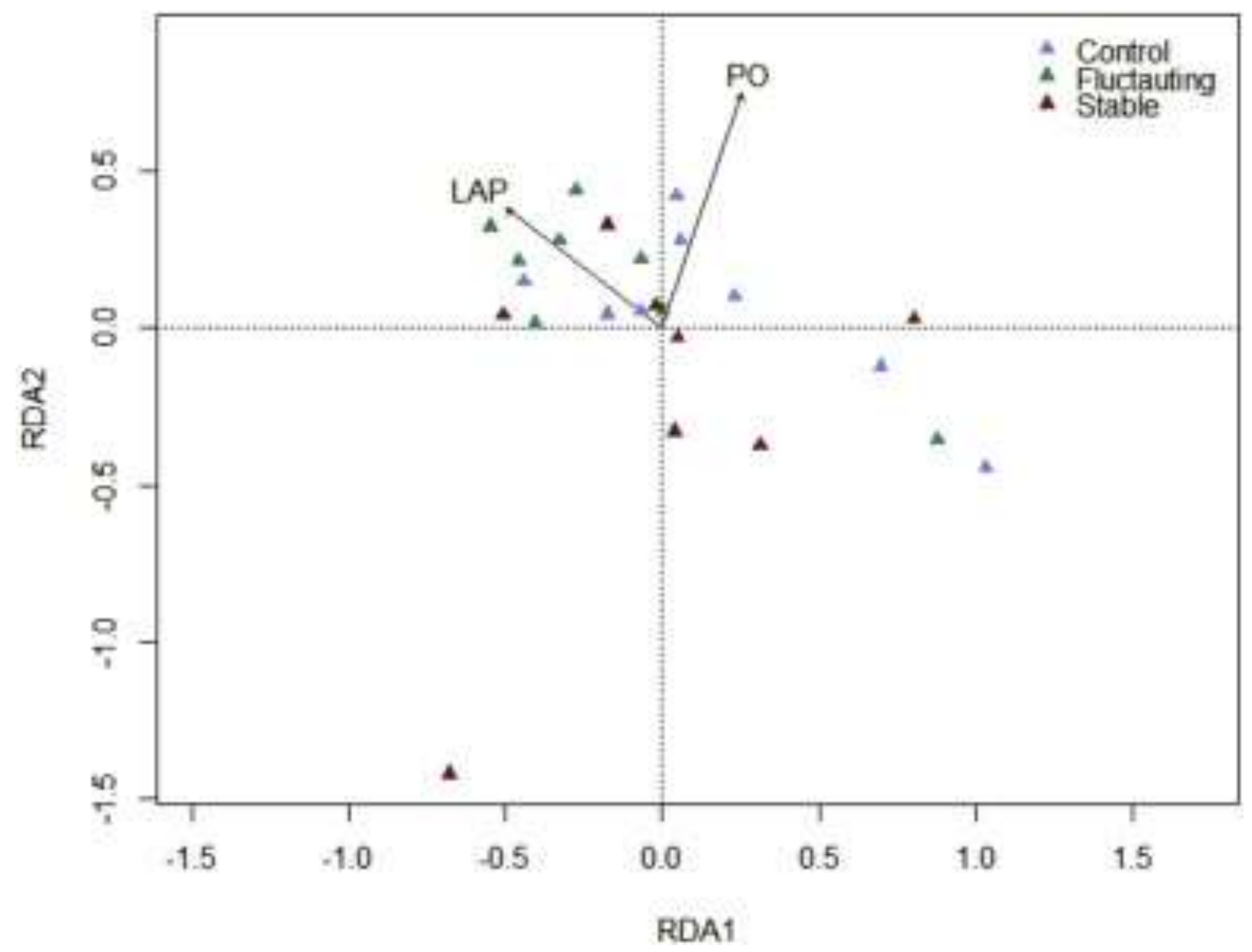


Table S1: Gamma-diversity of temperature treatment samples according to sampling day.

\begin{tabular}{rr}
\hline Day & Y-diversity \\
\hline-10 & 2784 \\
0 & 2261 \\
5 & 2150 \\
10 & 1225 \\
15 & 1853 \\
20 & 1176 \\
25 & 1752 \\
30 & 1969 \\
\hline
\end{tabular}




\section{Figure S1}

\section{Experimental Design}

16

14

12

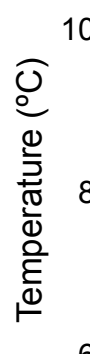

4

2

0

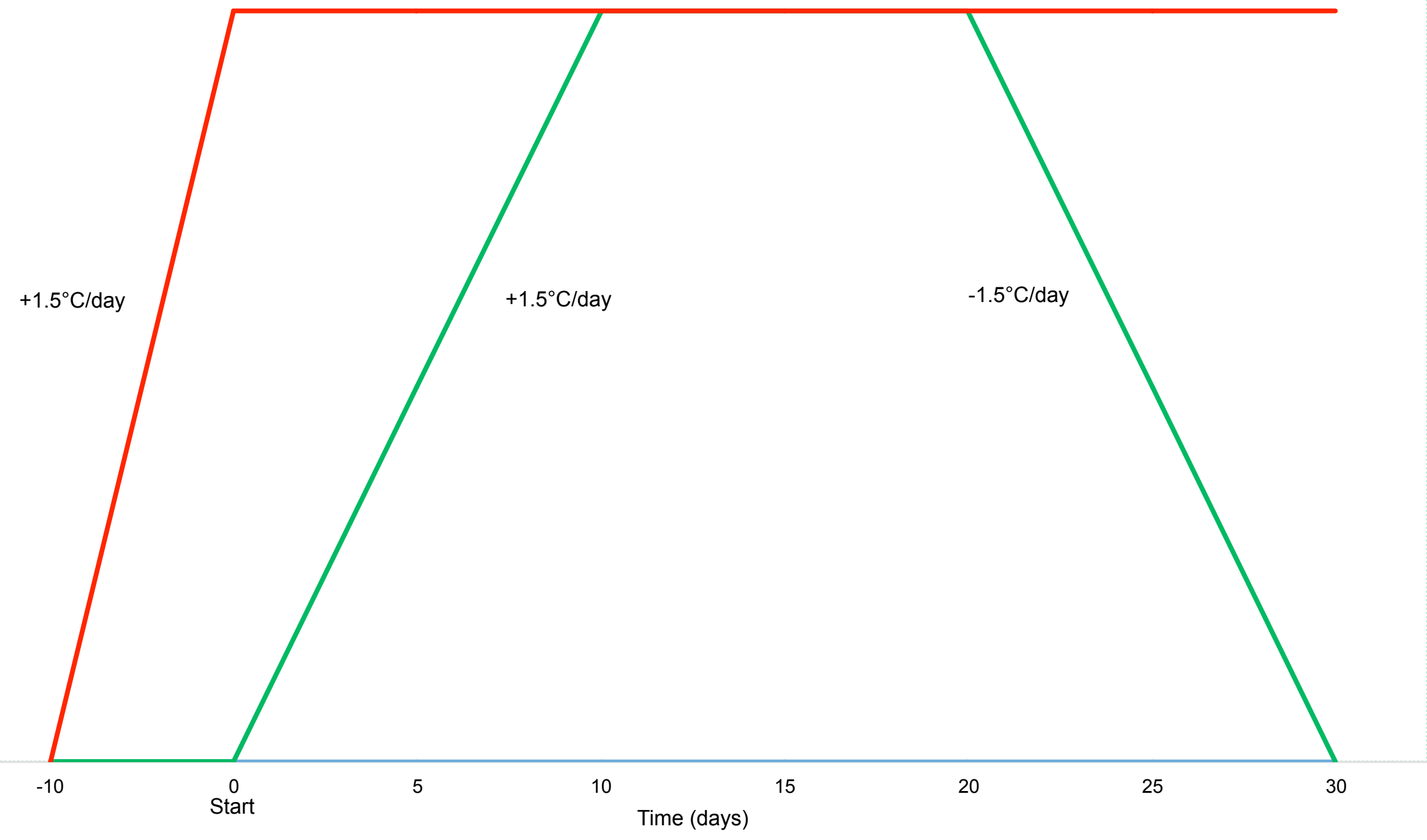


Figure S2

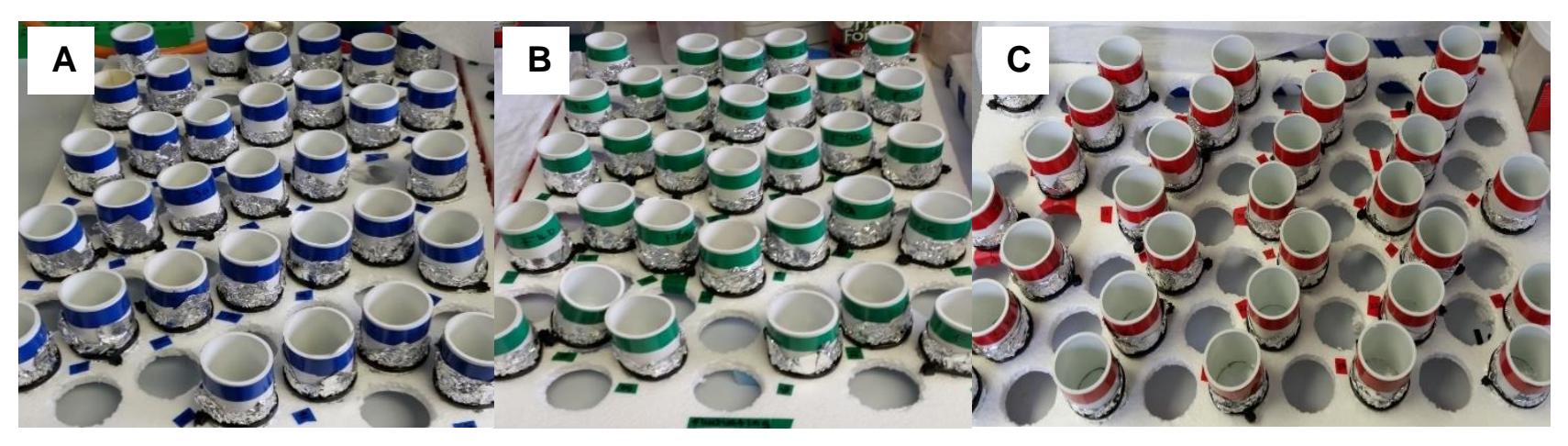


0,25 


\section{Actinobacteria}

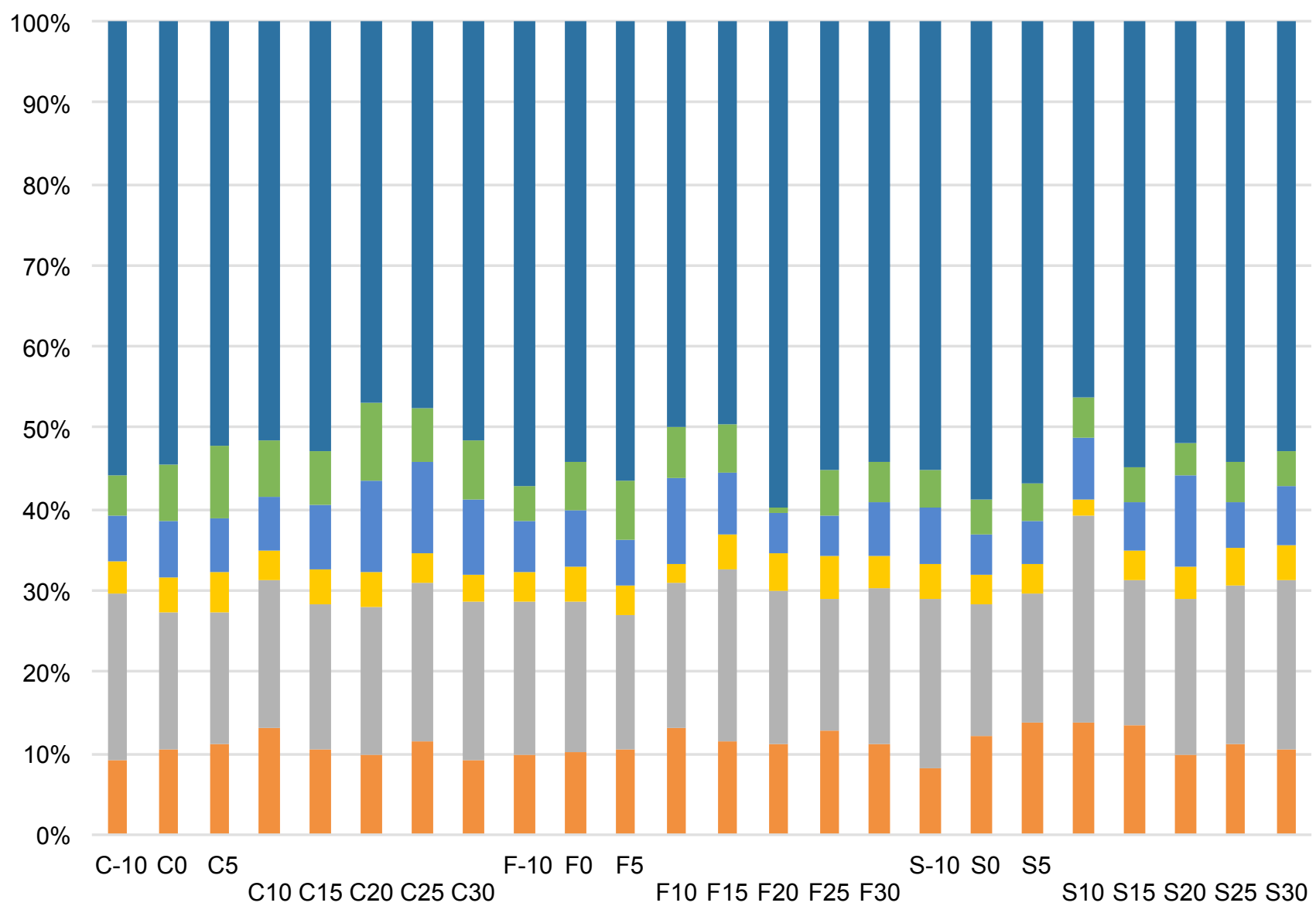

- Other

- Acidimicrobiia

- Actinobacteria

MB-A2-108

- Nitriliruptoria

Rubrobacteria

- Thermoleophilia 


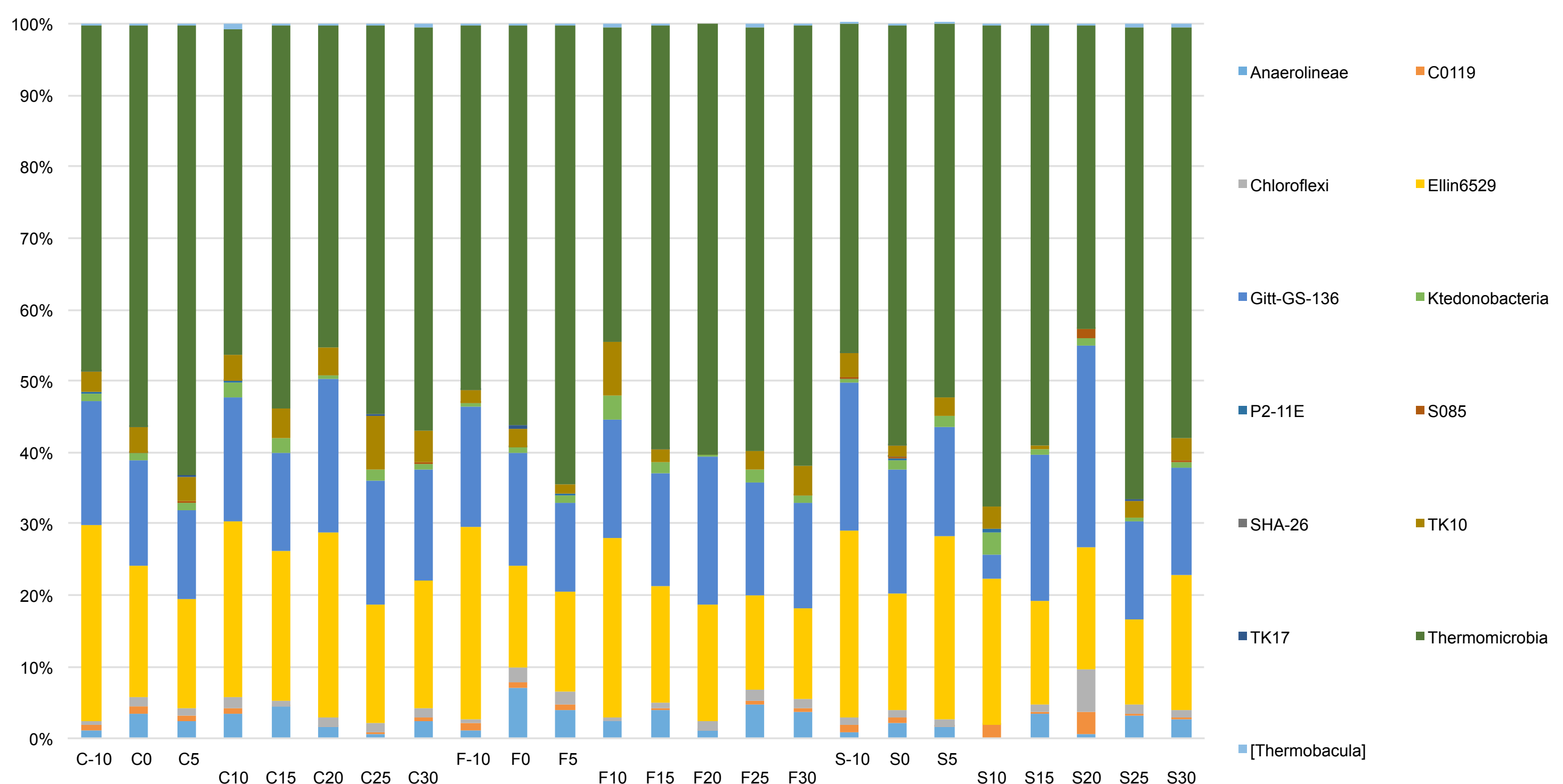

